\title{
Effect of Chronic Administration of Cadmium on Anxiety-Like, Depression-Like and Memory Deficits in Male and Female Rats: Possible Involvement of Oxidative Stress Mechanism
}

\author{
Mouloud Lamtai ${ }^{*}$, Jihane Chaibat ${ }^{1}$, Sihame Ouakki' ${ }^{1}$ Inssaf Berkiks ${ }^{1}$, El-Housseine Rifi' ${ }^{2}$, \\ Aboubaker El Hessni' ${ }^{1}$, Abdelhalem Mesfioui' ${ }^{1}$, Ali Tadlaoui Hbibi1,3, Hassna Ahyayauch ${ }^{1,3}$, \\ Azzouz Essamri', Ali Ouichou1
}

\begin{abstract}
${ }^{1}$ Unit of Nervous and Endocrine Physiology, Laboratory of Genetics, Neuroendocrinology and Biotechnology, Faculty of Science, University Ibn Tofail, Kenitra, Morocco

${ }^{2}$ Laboratory of Synthesis Organic and Extraction Processes, Department of Chemistry, Faculty of Science, University Ibn Tofail, Kenitra, Morocco

${ }^{3}$ Institut Supérieur des Professions Infirmières et Techniques de Santé (ISPISTS) route Casablanca, Rabat, Morocco ${ }^{4}$ Laboratory of Agro-Resources and Process Engineering, Faculty of Science, University Ibn Tofail, Kenitra, Morocco Email: ^mouloud-lamtai@hotmail.fr, ouichou@hotmail.com
\end{abstract}

How to cite this paper: Lamtai, M., Chaibat, J., Ouakki, S., Berkiks, I., Rifi, El-H., El Hessni, A., Mesfioui, A., Tadlaoui Hbibi, A., Ahyayauch, H., Essamri, A. and Ouichou, A. (2018) Effect of Chronic Administration of Cadmium on Anxiety-Like, Depression-Like and Memory Deficits in Male and Female Rats: Possible Involvement of Oxidative Stress Mechanism. Journal of Behavioral and Brain Science, 8, 240-268. https://doi.org/10.4236/jbbs.2018.85016

Received: January 17, 2018

Accepted: May 11, 2018

Published: May 14, 2018

Copyright $\odot 2018$ by authors and Scientific Research Publishing Inc. This work is licensed under the Creative Commons Attribution International License (CC BY 4.0).

http://creativecommons.org/licenses/by/4.0/

\begin{abstract}
The main objective of this work is to study the effect of chronic administration of cadmium (Cd) on the level of depression-like, anxiety-like, memory state and oxidative stress in male and female Wistar rats. For this purpose, this study was conducted with 24 rats for each gender. Four groups were constituted: (Group 1: Control): received saline solution $\mathrm{NaCl}$ (0.9\%), (Group 2: Cd-0.25; Group 3: Cd-0.5; Group 4: Cd-1): received daily $0.25 \mathrm{mg} / \mathrm{kg}, 0.5$ $\mathrm{mg} / \mathrm{kg}$ and $1 \mathrm{mg} / \mathrm{kg}$ of Cd respectively during 8 weeks. After treatment period, animals were tested in the open-field, elevated plus maze tests for anxiety-like behavior, and forced swimming test for depression-like behavior. The Y maze was used to evaluate the working memory and the Morris Water Maze, to evaluate space learning and spatial memory. The results revealed that in males, all doses of $\mathrm{Cd}$ provoke depression-like, while in females only the group treated with $1 \mathrm{mg} / \mathrm{kg} \mathrm{Cd}$ shows elevated depression-like behavior. In regard to anxiety-like behavior, $\mathrm{Cd}$ induces an anxiogenic effect in both genders tests. In the Y-Maze test, both males and females expressed a low percentage of alternations, suggesting that working memory was affected by $\mathrm{Cd}$ at 1 $\mathrm{mg} / \mathrm{kg}$. In the Morris Water Maze test, the space learning and spatial memory were significantly impaired in the group Cd-1. Neurochemical analysis showed that levels of nitric oxide and lipid peroxidation in the hippocampus
\end{abstract}


were significantly increased after Cd treatments. Overall analysis of our data revealed that $\mathrm{Cd}$ caused significant alterations in the examined parameters that were sex-dependent and dose-dependent.

\section{Keywords}

Cadmium, Depression-Like, Anxiety-Like, Memory, Oxidative Stress

\section{Introduction}

$\mathrm{Cd}$ is one of the most toxic elements that bio-accumulates in the environment [1], especially in industrial areas via atmospheric dispersion and ground contamination surrounding metal emitting industries [2]. Cd may find its way to the human population through food and beverage, drinking water, air, and cigarette smoking. Although its toxicity is well established, the interaction of this element within a biological system and its resulting potential for harm is less well established. Cd has a long biological half-life mainly due to its low rate of excretion from the body [3].

At peripheral level, prolonged exposure to $\mathrm{Cd}$ will cause toxic effect due to its accumulation over time in a variety of tissues, including kidneys, liver, central nervous system (CNS), and peripheral neuronal systems [4]. At central level, the transport of Cd through the blood-brain barrier (BBB) is the first step in regulating the entries of the metal into the CNS. Also, Cd can be taken from the nasal mucosa or olfactory pathways into the CNS [5]. It is well known in the CNS that the heavy metals, including $\mathrm{Cd}$, act as catalysts for biochemical reactions, regulators of gene expression, second messengers in signaling pathways and cofactors for many vital enzymes, such pathways implicated in regulating physiological, pathological and behavioral functions. Chronical exposure to $\mathrm{Cd}$ affects many nervous system functions [6] [7] with symptoms including headache and vertigo, olfactory dysfunction, parkinsonian symptoms like slowing of vasomotor functioning, peripheral neuropathy, decreased equilibrium, decreased ability to concentrate, and learning disabilities [8]. Thus, animal studies have shown that $\mathrm{Cd}$ exposure leads to motor hyperactivity, increased aggressive behavior, impaired social memory processes, and altered drinking behavior [9]. The hippocampus accumulates the divalent metals to a greater extent than do other parts of the brain [10]. Behavioral alterations following heavy metal exposure have been related to hippocampal dysfunction [11]. In this direction, animal studies involving $\mathrm{Cd}$ exposure also exhibit behavioral alterations. Rats exposed to Cd had decreased memory, as well as altered anxiety and fear responses [12]. These behavioral deficits correlated with levels of oxidative stress markers in the hippocampus of these rats [12]. However, mechanisms underlying Cd neurotoxicity remain not completely understood. Our hypothesis is that behavioral dysfunction (depression-like, anxiety-like and memory deficit) provoked after chronic administration of $\mathrm{Cd}$, might be linked to an increase in oxidative stress 
level in the hippocampus.

In this target, the present study was designed to determine the effects of chronic administration of $\mathrm{Cd}$ on animal behavior, especially on anxio-depressive disorders and memory deficits, and on levels of oxidative stress in male and female rats.

\section{Material \& Methods}

\subsection{Animals and Experimental Conditions}

This study was performed on adult male and female Wistar rats aged 8 to 9 weeks and having an average weight of $120 \pm 20 \mathrm{~g}$ from breeding of Faculty of life sciences, University Ibn Tofail. Animals of the same experimental group were housed together by six rats in each cage $(36 \mathrm{~cm}$ long, $20 \mathrm{~cm}$ wide and $15 \mathrm{~cm}$ high) and this was consistent for all rats. The space reserved for the breeding and the survival of the rats respects the well-being of the animals. All rats were maintained under LD 12/12 (12 h Light/12 h Darkness) and at a standard temperature $(21 \pm 1)^{\circ} \mathrm{C}$. Water and food were provided ad libitum. All experimental procedures were approved by the University Ethics Committee for Animal Experiments.

The rats are divided into 4 groups of 6 animals each ( 6 males and 6 females). For each sex, the different groups of rats are distributed as follows:

- 1st group: rats control receiving daily an intraperitoneal injection of Nacl $0.9 \%$.

- 2nd group: rats receiving daily a dose of $0.25 \mathrm{mg} / \mathrm{kg}$ of Cd.

- 3rd group: rats receiving daily a dose of $0.5 \mathrm{mg} / \mathrm{kg}$ of Cd.

- 4th group: rats receiving daily $1 \mathrm{mg} / \mathrm{kg}$ of $\mathrm{Cd}$.

Saline solution or $\mathrm{CdCl}_{2}$ (obtained from SIGMA-ALDRICH) used in the present work were injected intraperitoneally and chronically at the rate of one injection per day and this during 8 weeks according. All injections are carried out between 16:00 and 16:30. The rats were blindly treated and tested throughout the experiment. The route of $\mathrm{Cd}$ was selected according with previous works from literature [13] [14] [15] [16] and the chosen Cd doses, namely 0.25, 0.5 and $1 \mathrm{mg} / \mathrm{Kg}$ was consistent with natural doses of metal.

\subsection{Neurobehavioral Tests}

Twenty four hours after end of the 8 weeks corresponding to the treatment period, the animals were submitted to behavioral tests at the rate of one test per day, in the following order: the Open field test (OFT) followed by the Elevated plus maze (EPM), Forced swimming test (FST), Y maze and Morris water maze test (MWM), respectively [17] [18] [19]. The tests were performed between 8 am and $12 \mathrm{am}$.

\subsubsection{Anxiety-Like Measurement}

\section{- Open Field Test.}


The OFT is used to measure the anxiety-like behavior in rodents [20] [21]. The maze adopted is made of wood $(100 \mathrm{~cm} \times 100 \mathrm{~cm})$ enclosed with $40 \mathrm{~cm}$ high walls and placed under strong illumination (100 W, $2 \mathrm{~m}$ above the apparatus). The area was divided into 25 squares $(20 \mathrm{~cm} \times 20 \mathrm{~cm})$, defined as 9 central and 16 peripheral squares. At the beginning of the 10 min test, the animal was placed in the centre of the apparatus and its behavior was videotaped for subsequent analysis. The quantified parameters were the time spent in the center of the area (TCA) and the number of returns to the center (NRC). Central perimeter residence time is used as a measure of anxiety. The number of returns to the central area is also an indicator of the emotional reactivity. The central area of a novel environment is anxiogenic and aversive and the behavioral inhibition appears therefore as an avoidance behavior towards the central zone of the OFT. Locomotors activity is represented by number of total squares (NTS). The apparatus was cleaned between each examination using 7\% ethyl alcohol.

\section{- Test of the Elevated Plus Maze (EPM):}

The EPM is an ethological model of anxiety in rodents provoked by the novelty and repulsion as a result of elevation and illumination of the maze [22] [23]. This test is based on the creation of a conflict between the exploratory drive of the rat and its innate fear of open and exposed areas; it has been validated for the detection of emotional responses to anxiogenic and anxiolytic substances. Thus, increased open-arms exploration indicates reduced anxiety-related behavior. The EPM consists of a wooden plus-shaped platform elevated $70 \mathrm{~cm}$ above the floor. Two of the opposing arms $(50 \mathrm{~cm} \times 10 \mathrm{~cm})$ are closed by $40 \mathrm{~cm}$ high side and end walls, having an open roof. In order to avoid fall, the other two arms (open arms) were surrounded by $0.5 \mathrm{~cm}$ high edge, the four arms had at their intersection a central platform $(10 \mathrm{~cm} \times 10 \mathrm{~cm})$. A $100-\mathrm{W}$ lamp was placed exactly over the central platform. At the beginning of the test, the rats were placed on the central area of the maze facing an open arm. The following parameters of anxiety-related behavior were measured during the 5 min testing period: 1) entries into open arms (EOA), 2) time spent on the open arms (TOA), 3) and number of full entries into the arms (TAE). Decreased anxiety-like behavior is illustrated by a significant statistical increase of parameters in open arms (time and/or entries). The total number of the entries into all arms provides general hyperactivity. To eliminate any lingering olfactory cues, the apparatus was cleaned between each examination using $7 \%$ ethyl alcohol.

\subsubsection{Depression-Like Measurement in Forced Swimming Test (FST)}

The FST is an excellent maze used to assess the depressive-like behavior [24]. Swimming sessions were conducted by placing the rat in individual glass cylinders $($ height $=50 \mathrm{~cm}$; diameter $=30 \mathrm{~cm})$ containing $30 \mathrm{~cm}$ of water at $\left(23^{\circ} \mathrm{C} \pm\right.$ $2{ }^{\circ} \mathrm{C}$ ). During the session, rats were forced to swim for $5 \mathrm{~min}$ and the duration of immobility was measured. The latency to the first bout of immobility was also recorded starting immediately after placing the rats in the cylinder. A rat was judged immobile when it ceased all active behaviors (i.e. struggling, swimming 
and jumping) and remained passively floating or making minimal movements necessary to maintain the nostrils above water. High percent time floating is interpreted as an increased depressive-like response [24] [25].

\subsubsection{Cognitive Measurement}

\section{- Y-maze test:}

Spatial working memory was assessed by using the Y-maze spontaneous alternation test, as previously described [26]. Each mouse was placed in the center of the Y-maze and was free to explore the arena for $8 \mathrm{~min}$. The number of entries was counted per rat: an entry required that both hind paws of the animal had to be placed completely inside the arm. A rat would be making a triad when it visited all 3 arms consecutively. Between sessions, the maze was cleaned thoroughly with a $7 \%$ ethanol solution. As a measure for working memory, the percentage of alternations that the rat made was calculated, being the number of triads divided by the maximum possible alternations (i.e. the total number of entries minus 2$)^{\star} 100$. If a rat scored significantly above $50 \%$ alternations (the chance level for choosing the unfamiliar arm), this was indicative of functional working memory.

\section{- Morris Water Maze Test:}

The water maze [27] consisted of a circular polypropylene pool $(110 \mathrm{~cm}$ in diameter and $50 \mathrm{~cm}$ high) that was filled to a depth of $14 \mathrm{~cm}$ with room-temperature tap water $\left(24^{\circ} \mathrm{C}\right)$. The water was made opaque with the addition of $500 \mathrm{ml}$ of nontoxic white liquid tempera paint to ensure camouflage of the escape platform. The escape platform was constructed from a Plexiglas cylinder (30 cm high, $10 \mathrm{~cm}$ in diameter), which was painted white. The water level was $1 \mathrm{~cm}$ above the platform, making it invisible. The platform had a red top and colorful flag that were added for visible platform trials. The water maze was located in a room $\left(5.2 \mathrm{~m}^{\star} 2.4 \mathrm{~m}\right)$ with posters and furniture around the walls, which served as extra-maze visual cues. During testing, the room was dimly lit with diffuse white light (30 lx).

Rats were tested in the Morris water maze in four phases: acquisition, reversal, probe trial and visible platform trial [28]. During acquisition (4 trials/day for 3 days), rats were trained to swim to a hidden platform that was located in the Northeast quadrant. Each rat was removed from its holding cage using a plastic container and released from a randomly assigned start location (East, North, South or West). If the rat did not find the platform within $60 \mathrm{~s}$, it was guided to the platform and allowed to stay on it for approximately $10 \mathrm{~s}$. The inter-trial interval was approximately $5 \mathrm{~min}$. During reversal training ( 4 trials/day for 3 days) the platform was moved to the opposite quadrant (Southwest) and the same procedures described for acquisition training were used. On day 7 , rats were tested for spatial memory in a $60 \mathrm{~s}$ probe trial with no platform present and on day 8 rats were tested (four trials) using a visible platform, which was placed in the Northwest quadrant. 


\subsection{Biochemical Examination}

One day after end of behavioral tests, all animals were firstly anesthetized and then sacrificed by decapitation. Brains were quickly removed and maintained at low temperature on ice cold. The hippocampus was rapidly and gently removed and separated from surrounding tissues and homogenized in phosphate buffer at PH: $7.4(\mathrm{~W} / \mathrm{V})$, centrifuged at $1500 \mathrm{rpm}$ for $10 \mathrm{~min}$ and the resulting supernatant was used in the biochemical assays [18].

\section{- Nitrite/nitrate assay:}

In biological systems conversion of oxide nitric (NO) in aqueous solution to nitrite and nitrate is thought to favour nitrite production. The concentrations of nitrite in tissue homogenates were measured by using the diazotization method based on the Griess reaction, which is an indirect assay for NO production [29]. Briefly, samples $(500 \mu \mathrm{l})$ were pipetted into tubes and an equal volume of Griess reagent ( $1 \%$ sulphanylamide $(1 \mathrm{ml})$ and $0.1 \% \mathrm{~N}-1$-naphtylethylenediamine dihydrochloride ( $1 \mathrm{ml}$ ) in $2.5 \%$ ortophosphoric acid) was added to each tube. After incubation for 30 minutes at room temperature, absorbance was measured at $540 \mathrm{~nm}$. Linear regression analysis was used to calculate the nitrite concentrations in the serum and the tissue homogenates from the standard calibration curves of sodium nitrite. Tissue nitrite levels were expressed as $\mu \mathrm{mol} / \mathrm{g}$ tissue.

\section{- Lipid peroxidation assay.}

The formation of lipid peroxides during lipid peroxidation process were analysed by measuring the thiobarbituric-acid-reacting substances (TBARS) in cells, as previously described by Draper and Hadley [30]. Briefly, the samples were mixed with $1 \mathrm{ml}$ of trichloroacetic acid $10 \%$ and $1 \mathrm{ml}$ of thiobarbituric acid $0.67 \%$, then heated in a boiling water bath for $15 \mathrm{~min}$, and butanol $(2: 1 \mathrm{v} / \mathrm{v})$ was added to the solution. After centrifugation ( $800 \mathrm{~g} / 5 \mathrm{~min})$, the TBARS were determined by the absorbance at $535 \mathrm{~nm}$ [31].

\subsection{Statistical Analysis}

Behavioral data and biochemical parameters were analyzed by two-way ANOVA using SPSS version 22. Post hoc comparisons were made using the Tukey's test. ANOVA repeat measures were used for the Morris water maze test. All data are expressed as the means \pm standard error of the means (S.E.M.). In order to estimate the gender effect, we expressed the results for each sex as a percentage of the basal level (\% BL) represented by the respective control and considered as being $100 \%$. Differences were considered significant when $\mathrm{p}<0.05$, very significant when $\mathrm{p}<0.01$ and highly significant when $\mathrm{p}<0.001$.

\section{Results}

\subsection{Effect of Cadmium on the Levels of Anxiety-Like Measured in the OFT}

- Time spent in the central area (TCA) (Figure 1(a)):

The results summarized in Figure 1 show that the treatment factor significantly 
affected the TCA $\left(\mathrm{F}_{(3.32)}=29.22, \mathrm{p}<0.001\right)$.

In males, Cd affects TCA in dose-dependent manner between 0.25 and 1 $\mathrm{mg} / \mathrm{kg}$ in comparison with the control group (Cont/Cd-0.25: $\mathrm{p}<0.05$, Cont/Cd-0.5: $\mathrm{p}<0.001$ and Cont/Cd-1: $\mathrm{p}<0.001$ respectively). Cd induced mean average decrease of $29 \%, 57 \%$ and $55 \%$ at doses of $0.25,0.5$ and $1 \mathrm{mg} / \mathrm{kg}$

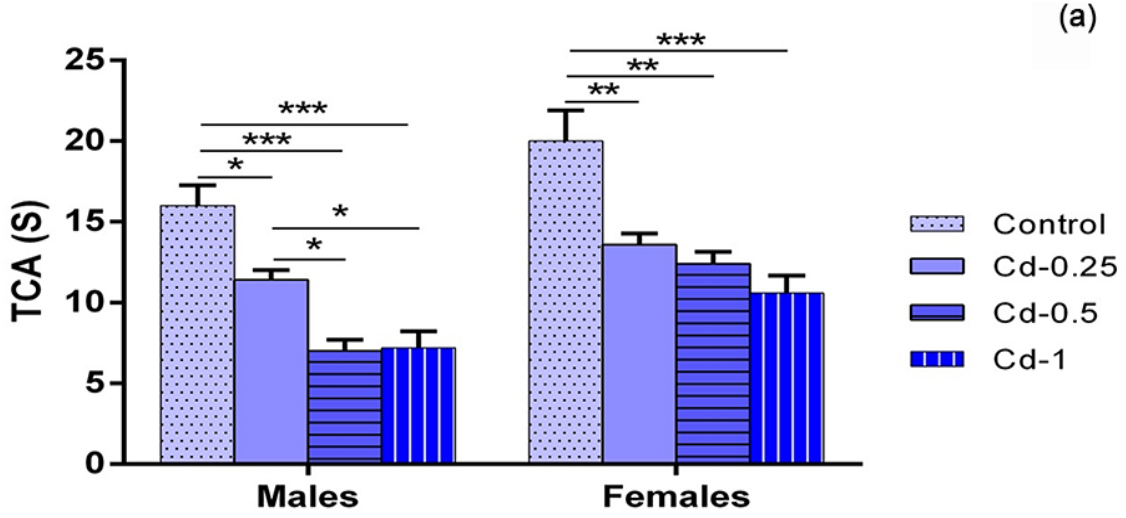

(b)

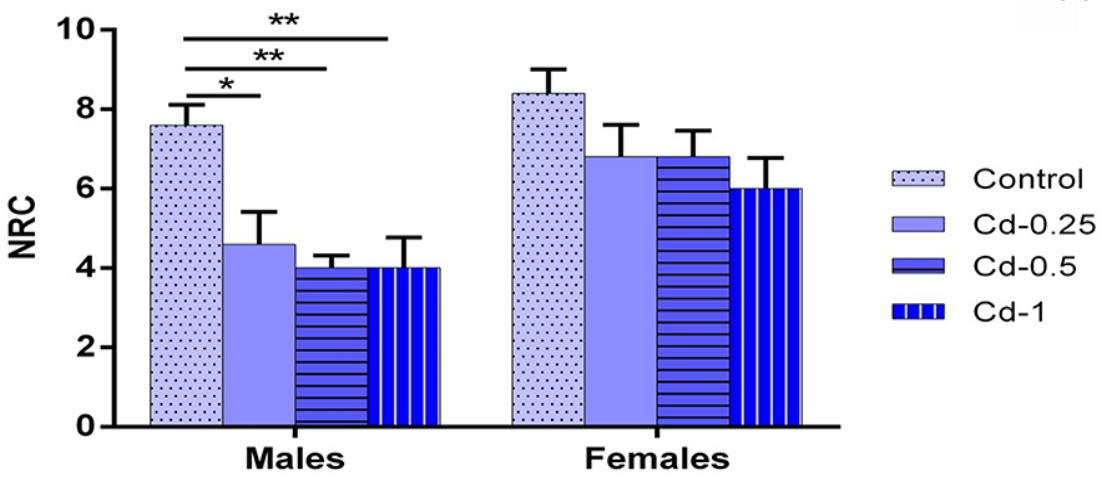

(c)

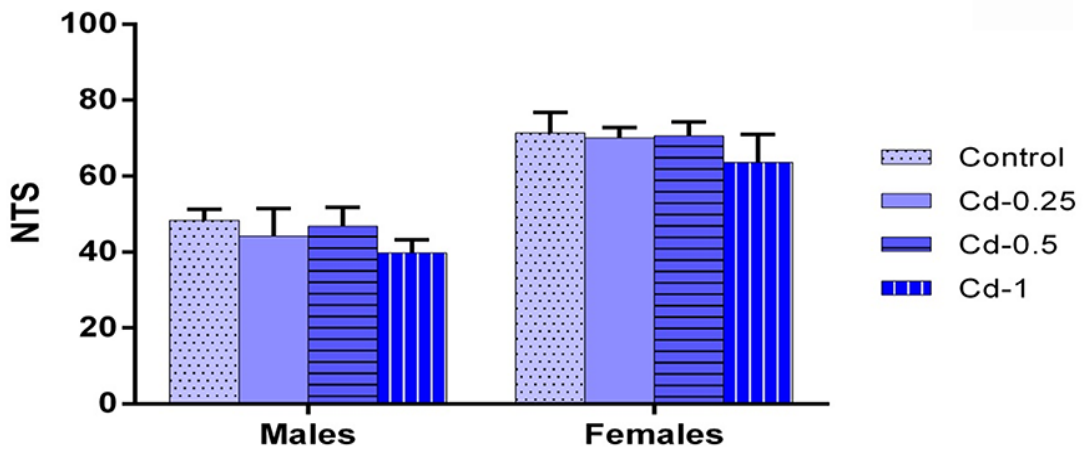

Figure 1. (a) Total amount time spent in the center (TCA); (b) Number of return into center area of the arena in the open-field behavior apparatus (NRC); (c) Number of total squares (NTS) in the open field by female and male rats after 2 month of treatment with $0.9 \%$ of $\mathrm{NaCl}$ (Control), $0.25 \mathrm{mg} / \mathrm{kg}$ (Cd-0.25) $0.5 \mathrm{mg} / \mathrm{kg}$ (Cd-0.5) and $1 \mathrm{mg} / \mathrm{Kg}(\mathrm{Cd}-1)$ of Cd. Results are expressed as mean \pm SEM. The significance level is $0.05 .{ }^{*} \mathrm{p}<0.05,{ }^{* *} \mathrm{p}<$ $0.01,{ }^{* * *} \mathrm{p}<0.001$. 
respectively. In addition, there is a statistically significant difference between the groups Cd-0.25/Cd-0.5 and Cd-0.25/Cd-1 ( $\mathrm{p}<0.05)$. In contrast, no difference was noted between Cd-0.5/Cd-1 groups ( $\mathrm{p}>0.05$ ).

In females, Cd affects TCA at doses of $0.25,0.5$ and $1 \mathrm{mg} / \mathrm{kg}$ in comparison with the control group (Cont/Cd-0.25: $\mathrm{p}<0.01$, Cont/Cd-0.5: $\mathrm{p}<0.01$ and Cont/Cd-1: $\mathrm{p}<0.001$ respectively). Cd induced mean average decrease of 32\%, $38 \%$ and $47 \%$ at doses of $0.25,0.5$ and $1 \mathrm{mg} / \mathrm{kg}$ respectively. No statistically significant difference was observed with comparing different treated Cd groups $(\mathrm{p}>0.05)$.

The sex effect was more visible when considering the relative comparison (TCA\% BL) between respective treated Cd groups in males and females. Indeed, the males of the groups Cd-0.5 showed a TCA significantly lower compared to females of similar groups $(\mathrm{p}<0.01)$.

- Number of Returns to the Center (NRC) (Figure 1(b)):

The treatment factor $\left(\mathrm{F}_{(3.32)}=7.93, \mathrm{p}<0.001\right)$ significantly affected the NRC. The effect of $\mathrm{Cd}$ is observed in males with referring to NRC parameter. At doses of $0.25,0.5$ and $1 \mathrm{mg} / \mathrm{kg}$, Cd significantly reduced the NRC compared with the control group (Cont/Cd-0.25: p < 0.05, Cont/Cd-0.5: p < 0.01 and Cont/Cd-1: $\mathrm{p}$ $<0.01$ respectively). Cd induced mean average decrease of $29 \%, 57 \%$ and $55 \%$ at doses of $0.25,0.5$ and $1 \mathrm{mg} / \mathrm{kg}$ respectively. While in females $\mathrm{Cd}$ did not induce any significant change in this parameter $(\mathrm{p}>0.05)$. It induced mean average decrease of $32 \%, 38 \%$ and $47 \%$ at doses of $0.25,0.5$ and $1 \mathrm{mg} / \mathrm{kg}$ respectively. In both sexes, no statistically significant difference was observed with comparing different treated Cd groups ( $\mathrm{p}>0.05$ ).

The sex effect was clear when considering the relative comparison (NRC \% $\mathrm{BL}$ ) between respective treated $\mathrm{Cd}$ groups in males and females. Indeed, the males of the group Cd- 0.5 showed a NRC significantly lower compared to females of similar group $(\mathrm{p}<0.05)$.

- Number of total squares (NTS) (Figure 1(c)):

Locomotors activity was unaffected by any treatment $\left(\mathrm{F}_{(3.32)}=1.04, \mathrm{p}>0.05\right)$, and no effect of sex $\left(F_{(1.32)}=1.49, p>0.05\right)$ was noted. The values of all groups were comparable. Even though is not significant, we observed a slight increase in the total activity of females compared to males.

\subsection{Effect of Cd on Anxiety Levels Measured in Elevated Plus Maze Test (EPM)}

- Time Spent in Open Arms (TOA) (Figure 2(a)):

Statistical analysis showed that TOA was significantly affected by the Cd treatment $\left(\mathrm{F}_{(3.32)}=48.30, \mathrm{p}<0.001\right)$.

In males, Cd decrease significantly TOA in all treated group in comparison with the control group $(\mathrm{p}<0.001)$. Cd induced mean average decrease of $48 \%$, $46 \%$ and $57 \%$ at doses of $0.25,0.5$ and $1 \mathrm{mg} / \mathrm{kg}$ respectively. No statistically significant difference was observed with comparing different treated $\mathrm{Cd}$ groups $(\mathrm{p}>0.05)$. 

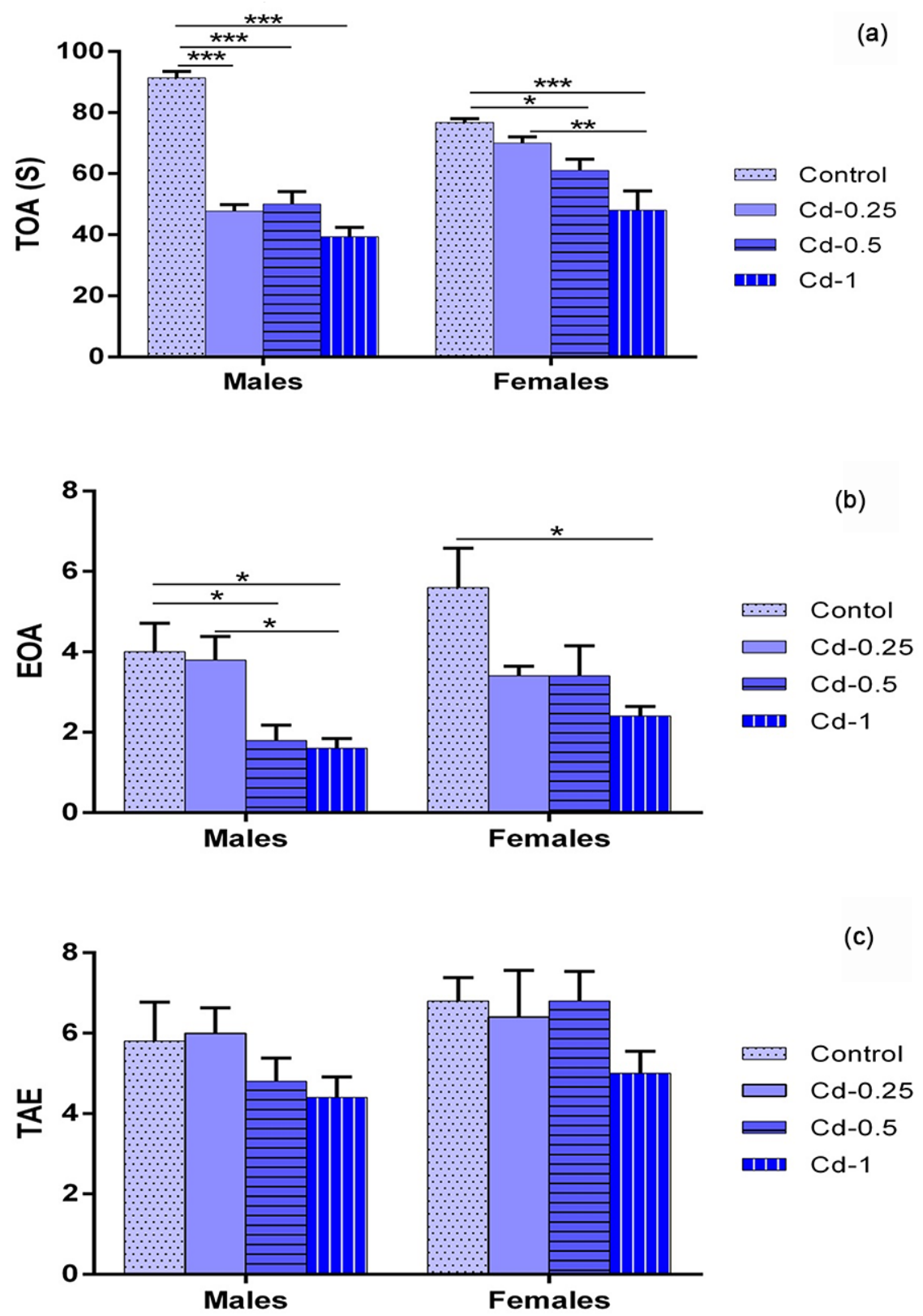

Figure 2. (a) Number of entries in exposed arms (EOA); (b) Total amount of time spent in exposed arms (TOA); (c) Total number of arms entries (TEA) in elevated plus maze by female and male rats after 2 month of treatment with $0.9 \%$ of $\mathrm{NaCl}$ (Control), $0.25 \mathrm{mg} / \mathrm{kg}$ (Cd-0.25) $0.5 \mathrm{mg} / \mathrm{kg}(\mathrm{Cd}-0.5)$ and $1 \mathrm{mg} / \mathrm{Kg}(\mathrm{Cd}-1)$ of Cd. Results are expressed as mean \pm SEM. The significance level is $0.05 .{ }^{*} \mathrm{p}<0.05,{ }^{* *} \mathrm{p}<0.01,{ }^{* *} \mathrm{p}<0.001$.

In females, Cd affects TOA in dose-dependent manner, since at doses of 0.5 and $1 \mathrm{mg} / \mathrm{kg}$ it decreases the TOA compared with the control group ( $<<0.05, \mathrm{p}$ $<0.001$ respectively), whereas at $0.25 \mathrm{mg} / \mathrm{kg} \mathrm{Cd}$ was not effective $(\mathrm{p}>0.05)$. The metal induced mean average decrease of $9 \%, 21 \%$ and $38 \%$ at doses of $0.25,0.5$ and $1 \mathrm{mg} / \mathrm{kg}$ respectively. In addition, there is a difference statistically significant between $\mathrm{Cd}-0.25 / \mathrm{Cd}-1$ groups $(\mathrm{p}<0.01)$. In contrast, no difference was noted between Cd-0.25/Cd-0.5 and Cd-0.5/Cd-1 groups ( $p>0.05$ ). 
The sex effect was more visible when considering the relative comparison (TOA\% BL) between respective treated Cd groups in males and females. Indeed, the males showed a TOA significantly lower compared to females of similar groups $(\mathrm{p}<0.01)$.

\section{- Entry to Open Arms (EOA) (Figure 2(b)):}

This parameter was affected by Cd treatment $\left(\mathrm{F}_{(3.32)}=8.97, \mathrm{p}<0.001\right)$ : In males, at doses of 0.5 and $1 \mathrm{mg} / \mathrm{kg}$, Cd decreases significantly the EOA in comparison with control group ( $\mathrm{p}<0.05$ ), while at dose of $0.25 \mathrm{mg} / \mathrm{kg}$ this metal did not induce any significant change in this parameter $(\mathrm{p}>0.05)$. In addition, there is a difference statistically significant between Cd-0.25/Cd-1 groups ( $\mathrm{p}<0.05)$. In contrast, no difference was noted between Cd-0.25/Cd-0.5 and Cd-0.5/Cd-1 groups $(\mathrm{p}>0.05)$.

In females, at dose of $1 \mathrm{mg} / \mathrm{kg}$, Cd decreases significantly the EOA in comparison with control group ( $\mathrm{p}<0.05$ ), while at doses of 0.25 and $0.5 \mathrm{mg} / \mathrm{kg}$ this metal did not induce any significant change in this parameter $(\mathrm{p}>0.05)$. No statistically significant difference was observed with comparing different treated $\mathrm{Cd}$ groups ( $\mathrm{p}>0.05)$.

Similar results were observed when considering the relative comparison (EOA \% BL) between treated $\mathrm{Cd}$ and control groups. Thus, Cd induced mean average decrease of $5 \%, 55 \%$ and $60 \%$ in males; of $40 \%, 40 \%$ and $58 \%$ in females respectively, at doses of $0.25,0.5$ and $1 \mathrm{mg} / \mathrm{kg}$ respectively. Also, the sex effect was visible when considering the relative comparison (EOA\% BL) between respective treated Cd groups in males and females. Indeed, the males of the group Cd- 0.25 showed a NRC significantly lower compared to females of similar group $(\mathrm{p}<0.05)$.

- Total entries in arms (TEA) (Figure 2(c)):

In contrast to TOA and EOA parameters, Cd was no significant effect on locomotors activity (TEA) represented whatever the dose considered $(p>0.05)$.

\subsection{Effect of Cadmium on Depressive-Like Performances Measured by Forced Swimming Test (FST)}

\section{- Immobility Time (TIM) (Figure 3(a)):}

Statistical analysis showed that TIM was significantly affected by sex factor $\left(\mathrm{F}_{(1.32)}=8.32, \mathrm{p}<0.01\right)$ and the Cd treatment $\left(\mathrm{F}_{(3.32)}=23.5, \mathrm{p}<0.001\right)$.

In males, Cd significantly affects TIM in dose-dependent manner, since at doses of $0.25,0.5$ and $1 \mathrm{mg} / \mathrm{kg}$ it increases the TIM compared with the control group ( $\mathrm{p}<0.05, \mathrm{p}<0.05$ and $\mathrm{p}<0.001$ respectively). Cd induced mean average increase of $42 \%, 49 \%$ and $123 \%$ at doses of $0.25,0.5$ and $1 \mathrm{mg} / \mathrm{kg}$ respectively. In addition, there is a difference statistically significant between Cd-0.25/Cd-1, Cd-0.5/Cd-1 groups $(\mathrm{p}<0.01)$. In contrast, no difference was noted between Cd-0.25/Cd-0.5 groups ( $\mathrm{p}>0.05$ ).

In females, at dose of $1 \mathrm{mg} / \mathrm{kg}$, Cd increases significantly TIM in comparison with control group $(\mathrm{p}<0.05)$, while at doses of 0.25 and $0.5 \mathrm{mg} / \mathrm{kg}$ this metal did not induce any significant change in this parameter $(\mathrm{p}>0.05)$. It induced mean 


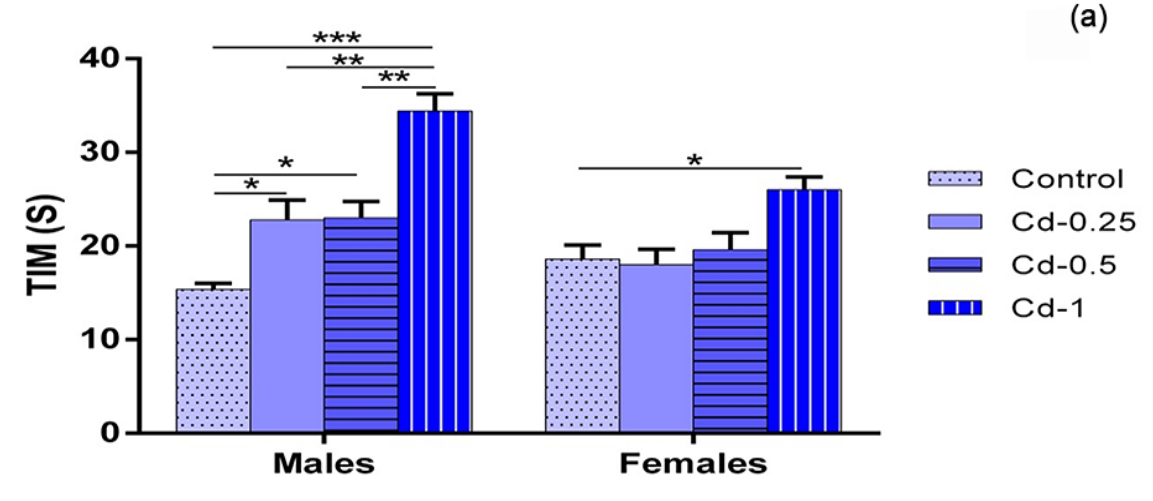

(b)

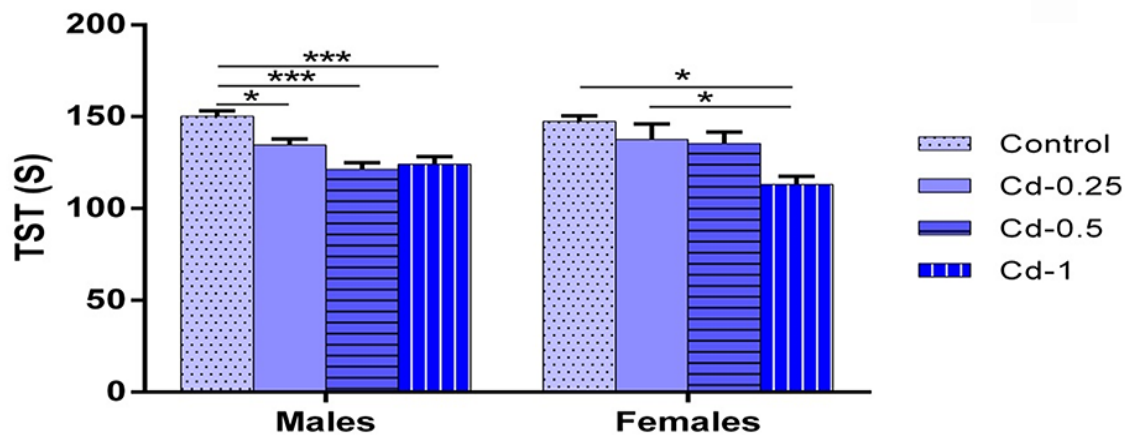

Figure 3. (a) Immobility time expressed in seconds (s) (TIM); (b) Struggling time in Forced swimming test expressed in seconds (s) by female and male rats after 2 month of treatment with $0.9 \%$ of $\mathrm{NaCl}$ (Control), $0.25 \mathrm{mg} / \mathrm{kg}$ (Cd-0.25) $0.5 \mathrm{mg} / \mathrm{kg}$ (Cd-0.5) and 1 $\mathrm{mg} / \mathrm{Kg}(\mathrm{Cd}-1)$ of $\mathrm{Cd}$. Results are represented as mean \pm SEM. The significance level is 0.05. ${ }^{\star} \mathrm{p}<0.05,{ }^{* *} \mathrm{p}<0.01,{ }^{* * *} \mathrm{p}<0.001$.

average increase of $0 \%, 5 \%$ and $39 \%$ at doses of $0.25,0.5$ and $1 \mathrm{mg} / \mathrm{kg}$ respectively. No statistically significant difference was observed with comparing different treated Cd groups $(\mathrm{p}<0.05)$.

The sex effect was clear when considering the relative comparison (TIM\% BL) between respective treated $\mathrm{Cd}$ groups in males and females. Indeed, the males showed a TIM significantly higher compared to females of similar groups $(\mathrm{p}<$ $0.001)$.

\section{- Struggling Time (TST) (Figure 3(b)):}

This parameter was affected by Cd treatment $\left(\mathrm{F}_{(3.32)}=13.67, \mathrm{p}<0.001\right)$ : The dose-dependent effect of $\mathrm{Cd}$ is observed in males with referring to TST parameter. At doses of $0.25,0.5$ and $1 \mathrm{mg} / \mathrm{kg}$, Cd decreases the TST compared with the control group ( $\mathrm{p}<0.05, \mathrm{p}<0.001$ and $\mathrm{p}<0.001$ respectively). No statistically significant difference was observed with comparing different treated Cd groups $(\mathrm{p}>0.05)$.

In females, at dose of $1 \mathrm{mg} / \mathrm{kg}$, Cd decreases the TST in comparison with control group ( $\mathrm{p}<0.05$ ), while at doses of 0.25 and $0.5 \mathrm{mg} / \mathrm{kg}$ this metal did not induce any significant change in this parameter $(\mathrm{p}>0.05)$. In addition, there is a 
difference statistically significant between Cd-0.25/Cd-1 groups $(\mathrm{p}<0.05)$. No difference was noted between Cd-0.25/Cd-0.5 and Cd-0.5/Cd-1 groups ( $\mathrm{p}>$ 0.05).

Similar results were observed when considering the relative comparison (TST \% BL) between treated Cd and control groups. Thus, Cd induced mean average decrease of $11 \%, 20 \%$ and $18 \%$ in males; of $7 \%, 24 \%$ and $18 \%$ in females respectively at doses of $0.25,0.5$ and $1 \mathrm{mg} / \mathrm{kg}$ respectively. The sex effect was observed when considering the relative comparison (TST\% BL) between respective treated Cd groups in males and females. Indeed, the males of the group Cd-0.5 showed a TST significantly lower compared to females of similar group $(\mathrm{p}<$ $0.05)$.

\subsection{Cadmium Effect on Memory}

\subsubsection{Y Maze Test (Figure 4)}

Spontaneous alternation percentage was affected by Cd treatment $\left(\mathrm{F}_{(3.32)}=6.12\right.$, $\mathrm{p}<0.01)$, but not by sex factor $\left(\mathrm{F}_{(1.32)}=0.75, \mathrm{p}>0.05\right)$.

In males and females, chronic treatment with $\mathrm{Cd}$ at dose of $1 \mathrm{mg} / \mathrm{kg}$ was associated with an decrease of spontaneous alternation percentage statistically significant compared to the control group $(\mathrm{p}<0.05)$, while at doses of 0.25 and 0.5 $\mathrm{mg} / \mathrm{kg}$ this metal did not induce any significant change in this parameter $(\mathrm{p}>$ $0.05)$. Indeed, no statistically significant difference was observed with comparing different treated Cd groups ( $\mathrm{p}>0.05$ ).

The relative comparison (Spontaneous alternation percentage \% BL) between treated $\mathrm{Cd}$ and control groups shows that $\mathrm{Cd}$ induced mean average decrease of $6 \%, 11 \%$ and $33 \%$ in males; of $15 \%, 19 \%$ and $29 \%$ in females respectively at doses of $0.25,0.5$ and $1 \mathrm{mg} / \mathrm{kg}$ respectively.

\subsubsection{Morris Water Maze}

\section{- Acquisition and reversal training (Figure 5):}

No significant differences in latency to reach the hidden platform in both phases acquisition trials (days $1-3$ ) and reversal trials (days $4-6$ ) between the treated and control groups ( $\mathrm{p}>0.05)$. Despite this, the group Cd-1 showed a non-significant increase in latency to reach the platform over days in acquisition and reversal learning.

- Percentage time spent in the correct quadrant during the probe trial (Figure 6):

The statistical analysis showd that the percentage of time spent in the correct quadrant is significantly affected the treatment with $\mathrm{Cd}\left(\mathrm{F}_{(3,32)}=7.79 ; \mathrm{p}<0.01\right)$.

In males and females, $\mathrm{Cd}$ at dose of $1 \mathrm{mg} / \mathrm{kg}$ was associated with a significant decrease of the percentage of time spent in the correct quadrant statistically significant compared to the control group ( $\mathrm{p}<0.05)$, while at doses of 0.25 and 0.5 $\mathrm{mg} / \mathrm{kg}$ this metal did not induce any significant change in this parameter $(\mathrm{p}>$ 0.05). Indeed, no statistically significant difference was observed with comparing different treated Cd groups ( $\mathrm{p}>0.05)$. 


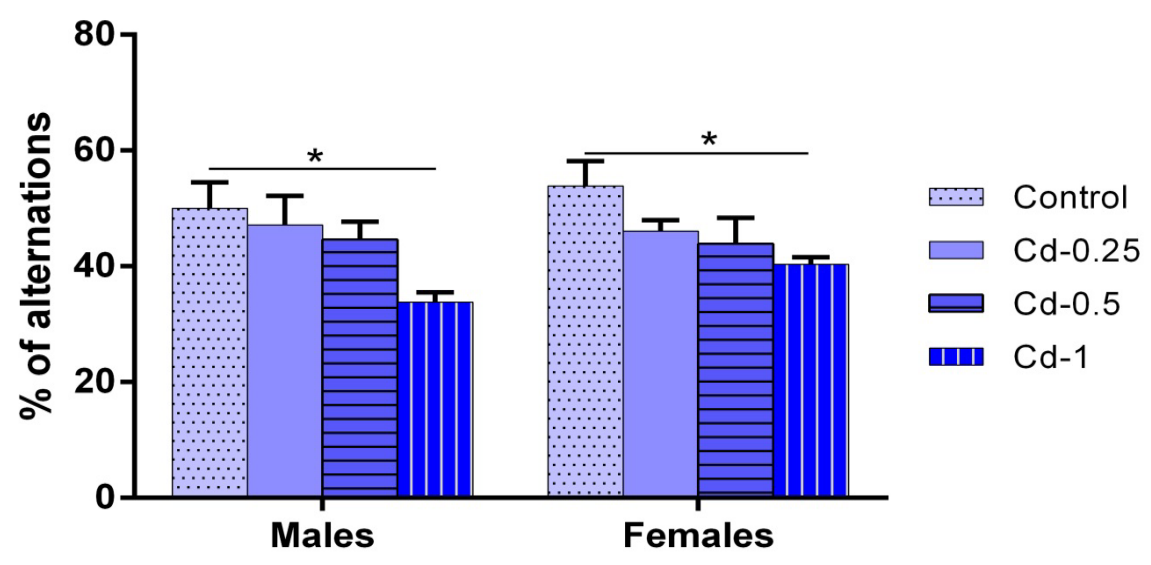

Figure 4. Spontaneous alternation percentage measured in Y-maze test in female and male rats after 8 weeks of treatment with $0.9 \%$ of $\mathrm{NaCl}$ (Control), $0.25 \mathrm{mg} / \mathrm{kg}$ (Cd-0.25) $0.5 \mathrm{mg} / \mathrm{kg}(\mathrm{Cd}-0.5)$ and $1 \mathrm{mg} / \mathrm{Kg}(\mathrm{Cd}-1)$ of Cd. Results are represented as mean $\pm \mathrm{SEM}$. The significance level is $0.05 .{ }^{\star} \mathrm{p}<0.05,{ }^{* *} \mathrm{p}<0.01,{ }^{* *} \mathrm{p}<0.001$.

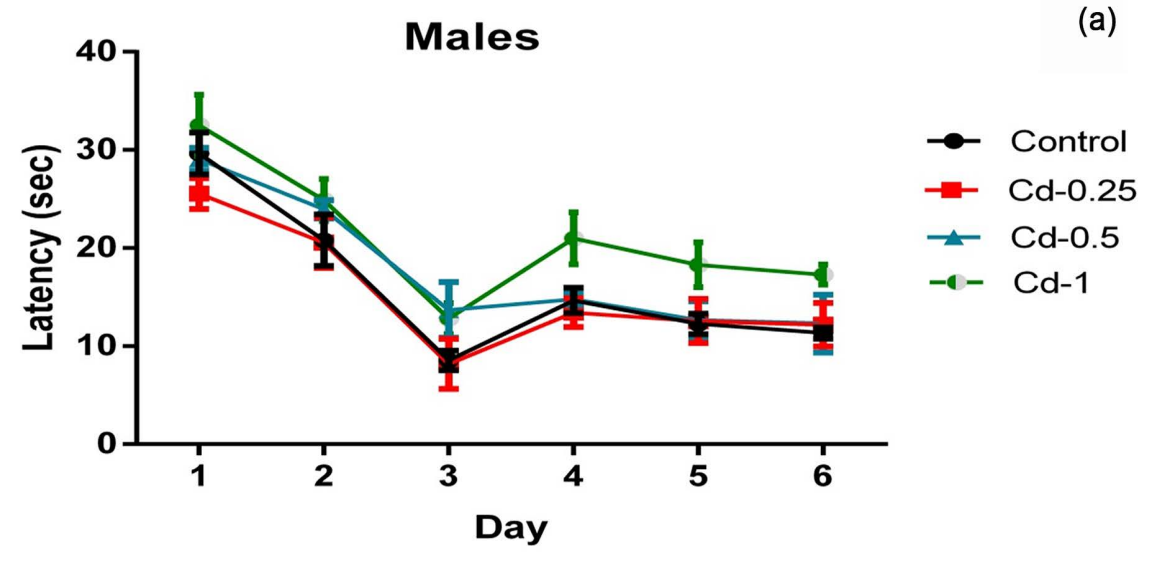

Females

(b)
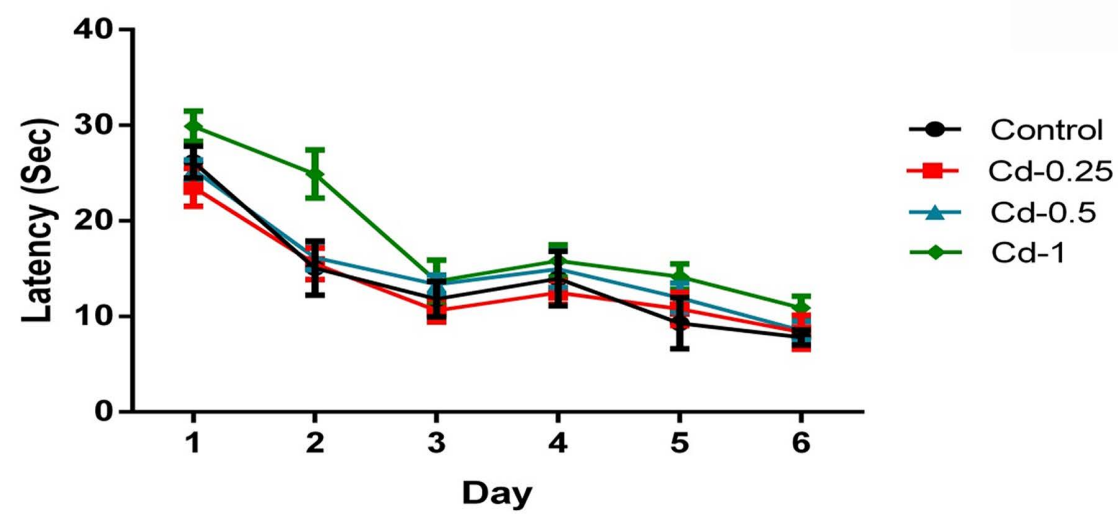

Figure 5. Latency to reach the hidden platform on each of the 6 days of training (acquisition 1 to reversal 3) in the Morris water maze, in male (a) and female rats (b) after 8 weeks of treatment with $0.9 \%$ of $\mathrm{NaCl}$ (Control), $0.25 \mathrm{mg} / \mathrm{kg}$ (Cd-0.25) $0.5 \mathrm{mg} / \mathrm{kg}$ $(\mathrm{Cd}-0.5)$ and $1 \mathrm{mg} / \mathrm{Kg}(\mathrm{Cd}-1)$ of $\mathrm{Cd}$. Results are represented as mean $\pm \mathrm{SEM}$. The significance level is $0.05{ }^{*} \mathrm{p}<0.05,{ }^{* *} \mathrm{p}<0.01,{ }^{* *} \mathrm{p}<0.001$. 


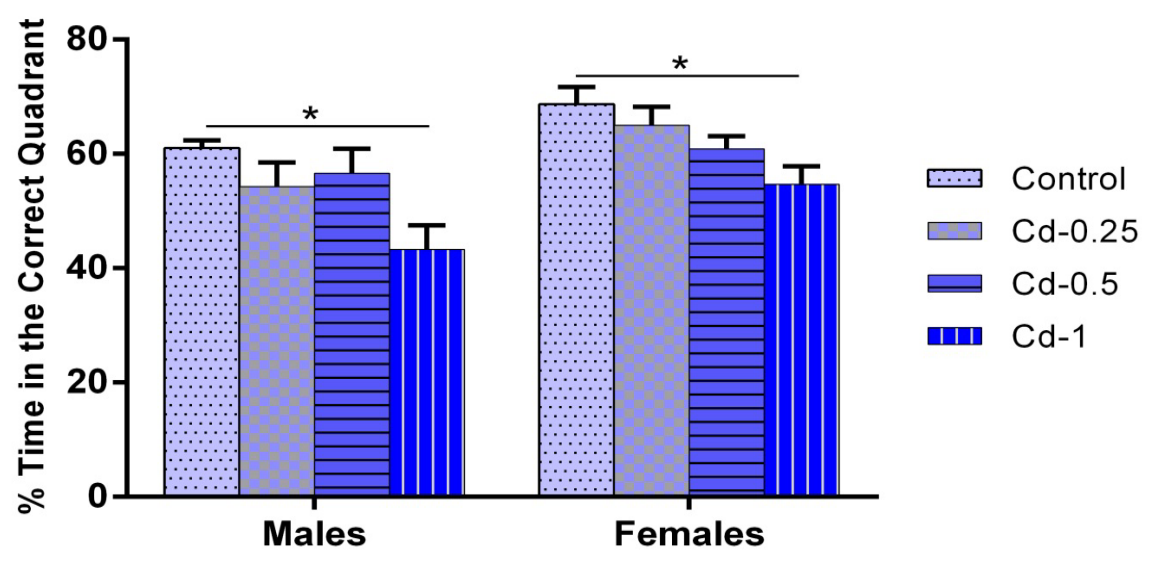

Figure 6. Percentage of time spent in the correct quadrant in the probe trial of the Morris water maze expressed as $\%$ in male and female rats after 8 weeks of treatment with $0.9 \%$ of $\mathrm{NaCl}$ (Control), $0.25 \mathrm{mg} / \mathrm{kg}$ (Cd-0.25) $0.5 \mathrm{mg} / \mathrm{kg}$ (Cd-0.5) and $1 \mathrm{mg} / \mathrm{Kg}$ (Cd-1) of Cd. Results are represented as mean $\pm \mathrm{SEM}$. The significance level is $0.05 .{ }^{\star} \mathrm{p}<0.05,{ }^{* *} \mathrm{p}<$ $0.01,{ }^{* * *} \mathrm{p}<0.001$.

The relative comparison (percentage of time spent in the correct quadrant \% $\mathrm{BL}$ ) between treated $\mathrm{Cd}$ and control groups shows that $\mathrm{Cd}$ induced mean average decrease of $12 \%, 8 \%$ and $29 \%$ in males; of $6 \%, 12 \%$ and $21 \%$ in females respectively at doses of $0.25,0.5$ and $1 \mathrm{mg} / \mathrm{kg}$ respectively.

- Visible platform test (Figure 7):

Latency to find the visible platform was unaffected by any treatment $\left(\mathrm{F}_{(3.32)}=\right.$ $0.84, \mathrm{p}>0.05)$, and no effect of $\operatorname{sex}\left(\mathrm{F}_{(1.32)}=0.008, \mathrm{p}>0.05\right)$. The values of all groups were comparable.

\subsection{Cadmium Effect on Oxidative Stress}

\section{- LPO in hippocampus (Figure 8):}

Statistical analysis showed that LPO reflected by TBARS levels was significantly affected by sex factor $\left.\left(\mathrm{F}_{(1.32)}=6.81, \mathrm{p}=0.0153<0.05\right)\right)$, and the Cd treatment $\left(\mathrm{F}_{(3.32)}=42.15, \mathrm{p}<0.001\right)$.

The results summarized in Figure 8 showed: In males, at doses of 0.5 and 1 $\mathrm{mg} / \mathrm{kg}$, Cd administration caused a significant increase in the level of TBARS in rat hippocampus compared to the control group ( $p<0.001)$, while at dose of $0.25 \mathrm{mg} / \mathrm{kg}$ this metal did not induce any significant change in this parameter ( $\mathrm{p}>0.05$ ). In addition, there is a difference statistically significant between Cd-0.25/Cd-0.5 and Cd-0.25/Cd-1 groups ( $\mathrm{p}<0.01$ and $\mathrm{p}<0.001$ respectively). While no difference was noted between Cd-0.5/Cd-1 groups ( $p>0.05)$.

In females, at dose of $1 \mathrm{mg} / \mathrm{kg}$, Cd increases significantly the LPO levels in comparison with control group, while at doses of 0.25 and $0.5 \mathrm{mg} / \mathrm{kg}$ this metal did not induce any significant change in this parameter $(\mathrm{p}<0.001, \mathrm{p}>0.05$ and $\mathrm{p}>0.05$ respectively). There is a difference statistically significant between Cd-0.25/Cd-1 and Cd-0.5/Cd-1 groups $(\mathrm{p}<0.01)$. No difference was noted between Cd-0.25/Cd-0.5 groups ( $\mathrm{p}>0.05)$. 


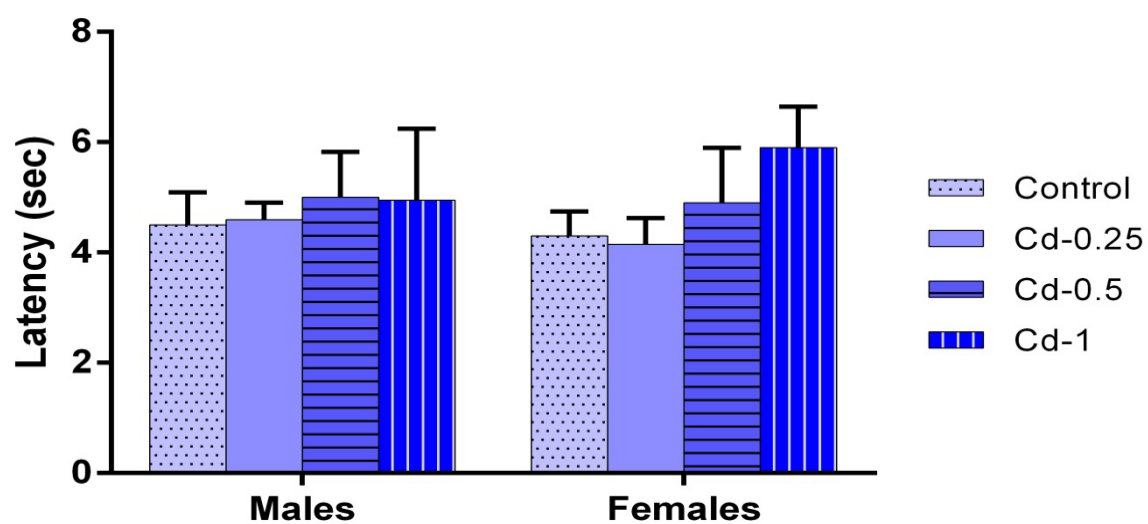

Figure 7. Latency to reach the visible platform for each strain in the Morris water maze expressed in second (S), in male and female rats after 8 weeks of treatment with $0.9 \%$ of $\mathrm{NaCl}$ (Control), $0.25 \mathrm{mg} / \mathrm{kg}$ (Cd-0.25) $0.5 \mathrm{mg} / \mathrm{kg}(\mathrm{Cd}-0.5)$ and $1 \mathrm{mg} / \mathrm{Kg}(\mathrm{Cd}-1)$ of Cd. Results are represented as mean \pm SEM. The significance level is $0.05 .{ }^{\star} \mathrm{p}<0.05,{ }^{\star *} \mathrm{p}<$ $0.01,{ }^{* * *} \mathrm{p}<0.001$.

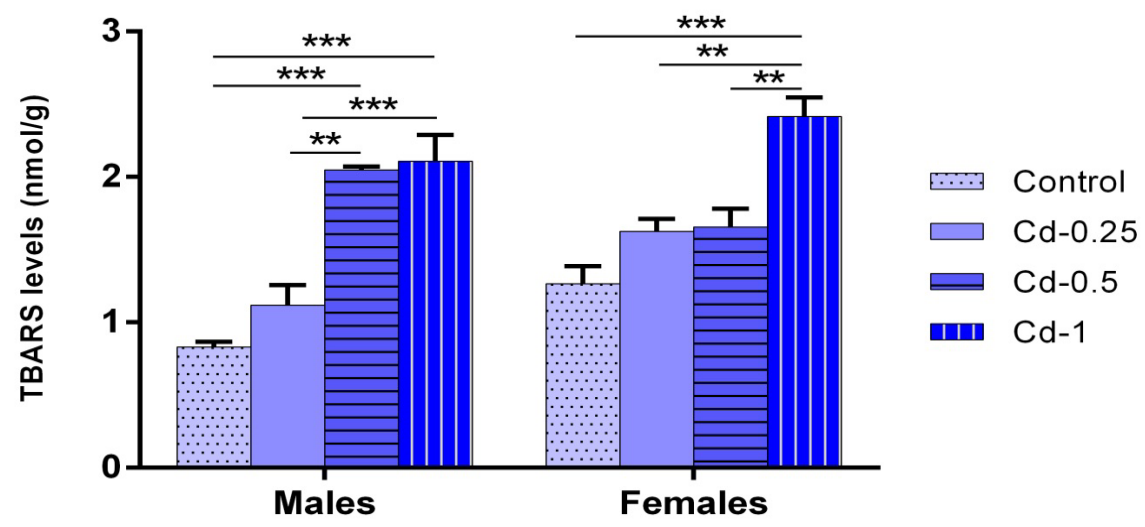

Figure 8. Determination of the lipid peroxidation levels in hippocampus, TBARS levels expressed in $\mathrm{nmol} / \mathrm{g}$ tissu in male and female rats after 8 weeks of treatment with $0.9 \%$ of $\mathrm{NaCl}$ (Control), $0.25 \mathrm{mg} / \mathrm{kg}$ (Cd-0.25) $0.5 \mathrm{mg} / \mathrm{kg}$ (Cd-0.5) and $1 \mathrm{mg} / \mathrm{Kg}$ (Cd-1) of Cd. Results are represented as mean \pm SEM. The significance level is 0.05 . ${ }^{\star} \mathrm{p}<0.05,{ }^{\star *} \mathrm{p}<$ $0.01,{ }^{* * *} \mathrm{p}<0.001$.

Similar results were observed when considering the relative comparison (TBARS \% BL) between treated $\mathrm{Cd}$ and control groups. Thus, $\mathrm{Cd}$ induced mean average increase of $34 \%, 146 \%$ and $153 \%$ in males; of $28 \%, 31 \%$ and $91 \%$ in females respectively at doses of $0.25,0.5$ and $1 \mathrm{mg} / \mathrm{kg}$ respectively. In addition, the sex effect was observed when considering the relative comparison (TBARS\% BL) between respective treated $\mathrm{Cd}$ groups in males and females. Indeed, the males of the groups Cd-0.5 and Cd-1 showed a TBARS levels significantly higher compared to females of similar groups ( $\mathrm{p}<0.001$ and $\mathrm{p}<0.05$ respectively).

\section{- NO concentrations in hippocampus (Figure 9):}

This parameter was affected by Cd treatment $\left(\mathrm{F}_{(3.32)}=59.79, \mathrm{p}<0.001\right)$, but not by sex factor $\left(\mathrm{F}_{(1.32)}=0.22, \mathrm{p}>0.05\right)$. No interaction was found between treatment and $\left.\operatorname{sex} \mathrm{F}_{(3.32)}=0.72, \mathrm{p}>0.05\right)$. 


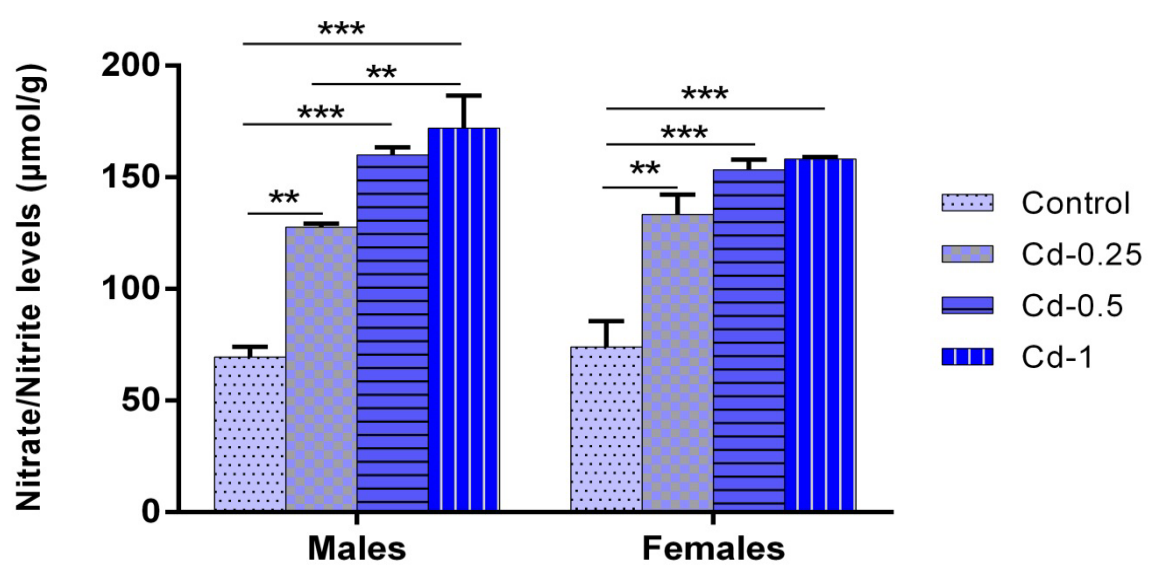

Figure 9. Determination of the nitric oxide (NO) levels in hippocampus, expressed in $\mu \mathrm{mol} / \mathrm{g}$ tissu in male and female rats after 8 weeks of treatment with $0.9 \%$ of $\mathrm{NaCl}$ (Control), $0.25 \mathrm{mg} / \mathrm{kg}$ (Cd-0.25) $0.5 \mathrm{mg} / \mathrm{kg}(\mathrm{Cd}-0.5)$ and $1 \mathrm{mg} / \mathrm{Kg}(\mathrm{Cd}-1)$ of Cd. Results are represented as mean $\pm \mathrm{SEM}$. The significance level is $0.05 .{ }^{*} \mathrm{p}<0.05,{ }^{* *} \mathrm{p}<0.01,{ }^{* *} \mathrm{p}<$ 0.001 .

In males and also females, $\mathrm{Cd}$ affects the NO levels in dose-dependent manner, since at doses of 0.25 and $1 \mathrm{mg} / \mathrm{kg}$ it increases the nitrite/nitrate levels (nitric oxide; NO) in comparison with the control group ( $<<0.01, \mathrm{p}<0.001$ and $\mathrm{p}$ $<0.001$ respectively). The metal induced mean average increase of $83 \%, 130 \%$ and $147 \%$ in males, of $80 \%, 107 \%$ and $113 \%$ in females, at doses of $0.25,0.5$ and $1 \mathrm{mg} / \mathrm{kg}$ respectively. In addition, in males there is a statistically significant difference between the groups Cd-0.25/Cd-1 $(\mathrm{p}<0.01)$ and no difference was noted between Cd-0.25/Cd-0.5 and Cd-0.5/Cd-1 groups ( $p>0.05$ ). In contrast, in females no statistically significant difference was observed with comparing different treated Cd groups ( $\mathrm{p}>0.05)$.

The sex effect was observed when considering the relative comparison (NO\% $\mathrm{BL}$ ) between respective treated $\mathrm{Cd}$ groups in males and females. Indeed, the males of the groups Cd-1 showed a NO levels significantly higher compared to females of similar groups $(\mathrm{p}<0.05)$.

\section{Discussion}

The main objective of this study was to determine the effects of chronic exposure to Cd on animal behavior, in particular on affective, cognitive disorders and on levels of oxidative stress. The assessment of anxiety-like and depression-like behaviors is based on the use of validated OFT, EPM and FST behavioral tests. While spatial working memory and spatial learning have been evaluated using respectively the Y-maze test and the Morris water maze test. Oxidative stress has been determined by measurement of NO and TBARS directly associated with LPO.

The evaluation of the anxiety levels obtained in the OFT is still confirmed by the use of EPM, one of the most used anxiety models [32]. Based on the behavioral study of rats in the OFT and EPM tests, the present study showed that $\mathrm{Cd}$, 
administered chronically, exerts an anxiogenic effect in rats. In the OFT, Cd decreases the TCA and NRC parameters without modifying the locomotor activity represented by the NTS parameter. With regard to EPM, Cd decreases TOA and EOA parameters without modifying the TAE parameter. In two tests, Cd exerts its effects in a dose-dependent manner; anxiogenic action starts at $0.25 \mathrm{mg} / \mathrm{kg}$ and reaches a maximum at the dose of $1 \mathrm{mg} / \mathrm{kg}$. It should be noted that at 0.125 $\mathrm{mg} / \mathrm{kg}$, Cd did not alter deferent parameters in anxiety behavioral tests (result not shown). The anxiogenic action of $\mathrm{Cd}$ reported in this study is consistent with numerous studies focusing on the relationship between $\mathrm{Cd}$ and behavioral studies in rodents. Thus, in rats increased anxiety levels in OFT, in a dose-dependent manner, was obtained after acute intoxication with $\mathrm{Cd}$ injected intraperitoneally at three different doses (1 - $3 \mathrm{mg} / \mathrm{kg})$ [19]. An increase in anxiogenic behavior, in the EPM was also observed following Cd gavage despite the use of high levels of the metal $(2.5 \mathrm{mg} / \mathrm{kg})$ [33]. The effect of Cd are transgenerational, since the transmission of anxiogenic effects has been shown in the progeny after maternal exposure to metal [34].

The present study also showed that chronic administration of Cd caused an increase in TIM in a dose-dependent manner between 0.25 and $1 \mathrm{mg} / \mathrm{kg}$. Since, the locomotor activity measured in the OFT was not affected by this treatment, it was suggested that the behavioral differences in the Porsolt test would induced by changes in the depressive-like state. Our study was corroborated by the observation of Haider (2014) which reported that in FST, the TIM was significantly increased by acute administration of Cd at a dose of $3 \mathrm{mg} / \mathrm{kg}$ as well as other two dose, indicating dose-dependent effects ( $1-2 \mathrm{mg} / \mathrm{kg}$ ) [19]. Compared with other studies, our work has the advantage of administering very small amounts of $\mathrm{Cd}$ in a chronic way over a long period of the time and of obtaining effect at lower doses, since the Cd efficiency appears from $0.25 \mathrm{mg} / \mathrm{kg}$.

The question is how the Cd acts to induce its effects on anxio-depressive behavior. $\mathrm{Cd}$, after chronic exposure, could affect the integrity or permeability of the $\mathrm{BBB}$ consequently penetrating in the brain of developing and adult rats, leading to brain accumulation and cellular dysfunction [5] [35] [36]. This accumulation of $\mathrm{Cd}$ in the brain after Cd treatment, revealed by the study of Jyostna and Sudhakar [17], provoking morphological and biochemical modifications, especially in certain of CNS structures and then leading to possible neurobehavioral alterations such as affective and cognitive disorders [37] [38]. It is also well known in the CNS that the Cd acts as catalysts for biochemical reactions, regulators of gene expression, second messengers in signaling pathways and cofactors for many vital enzymes, such pathways implicated in regulating physiological, pathological and behavioral functions. In this direction, $\mathrm{Cd}$ is a neurotoxic substance that generally inhibits the enzymes involved in the synthesis of neurotransmitters such as serotonergic system, which is one of several systems involved in the response to anxiety and depression [39]. This is based on the observation that people with low serotonin $(5 \mathrm{HT})$ levels are more prone to depres- 
sion and anxiety [40]. Indeed, several studies have shown that exposure to Cd produces alterations in the serotonergic system, which may explain the anxiogenic and depressive effect of this metal observed in our study. A decrease in levels of 5-HT, dopamine in all regions of the brain including the anterior brain (hippocampus and striatum) has been shown $24 \mathrm{~h}$ after exposure to Cd [41] [42]. Decreased levels of 5-HT and 5-HIAA in the cortex and hippocampus in progeny was also observed following an exposure to low $\mathrm{Cd}$ concentrations in drinking water during the lactation period [43].

In this study, we also reported that learning and working memory were affected by Cd. Generally, animals that have undergone hippocampal lesions have poor performance in Y maze and Morris water maze test [44], a structure known to undergo morphological changes in rats exposed to heavy metals [45] [46]. In our study, working memory evaluated in Y maze test was impaired only in male and female rats exposed to $\mathrm{Cd}$ at $1 \mathrm{mg} / \mathrm{kg}$, which exhibited significantly lower alternation behaviour scores in comparison with the control group. This is consistent with the study reported by Lukawski which showed that decrease in percentages of alterations was caused by an intraperitoneal administration of $\mathrm{Cd}$ in adult female mice at a dose of $0.7 \mathrm{mg} / \mathrm{kg}$ for 10 days [47]. The similar effects were observed in adult male rats received during 60 days $\mathrm{Cd}$ dissolved in water at concentrations of 5 and $50 \mathrm{mg} / \mathrm{L}$ [18]. In Morris water maze, Cd exposure impaired acquisition and reversal performance, a higher latency was observed in rats exposed to this metal at dose of $1 \mathrm{mg} / \mathrm{kg}$ compared to control rats with a non-significant difference. In addition, a deficit of memorization was shown in animals $\mathrm{Cd}$ treated, explained by a significant decrease in the time spent in the quadrant where platform it was localized (Probe Test). This study is consistent with the Jyotsna and Sudhakar study (2016) which showed that the administration of $5 \mathrm{mg} / \mathrm{kg}$ for three weeks, increased latency in all test phases [17]. Also, in rats increased latency in MWM, was obtained after acute intoxication with $\mathrm{Cd}$ at 1,2 and $3 \mathrm{mg} / \mathrm{kg}$ [19].

Our study supported by the work mentioned above confirmed that learning and memory was impaired by chronic $\mathrm{Cd}$ administration. These impairments of spatial memory, which are generally caused by hippocampal lesions [48] may be due to the disturbance of the hippocampal circuit and its vast connections [49]; the hippocampus especially being indispensable in the integration of spatial information. Therefore, the memory deficit observed in our study might be related to alteration in a number of cellular and molecular parameters in the hippocampus and/or other brain areas. As shown in the studies of Méndez-Armenta [48] and Kaoud [18], the histopathological examination of the brain reveled that $\mathrm{Cd}$ intoxication caused neuronal degeneration, atrophied and necrotic pyramidal cells in hippocampus.

Another important aspect to be discussed here is the effect of $\mathrm{Cd}$ on the cholinergic system, which plays a crucial role in the process of learning and memory [50]. An association between impairment of learning and decreased brain choli- 
nergic activity has demonstrated [51]. Acetylcholinestrase (AChE) is an enzyme responsible for hydrolyzing and deactivating acetylcholine in the body, it can modulating synaptic plasticity thought to be important for storing memory and long term potentiation in brain regions. Alterations in this enzyme level are indicative to impairment of cholinergic function [52]. Also it is a good indicator of sublethal toxicity by heavy metals [53]. The effect of $\mathrm{Cd}$ on $\mathrm{AChE}$ was shown in several studies. A decreased in AChE activity in the hippocampus, cerebellum and hypothalamus following $\mathrm{Cd}$ administration at a dose of $2 \mathrm{mg} / \mathrm{kg}$ has demonstrated by Gonçalves [36]. Similar results have been found by others researchers [19] [33] [54]. Additionally, it is reported that Cd generally impairs enzymes involved in the synthesis of neurotransmitters. It is suggested that $\mathrm{Cd}$ has been reported to be an inactivator metal, which may induce conformational changes leading to AChE inhibition [54] [55]. This inhibition decreased the acetylcholine hydrolysis hence decreasing the reuptake of choline. In addition to that, several studies reported that calmodulin, a protein capable of associating with calcium ions promoting the exocytosis process, is unable to differentiate between $\mathrm{Ca}^{2+}$ and $\mathrm{Cd}$ which ultimately produces alteration in cholinergic system by interfering with the process of exocytosis [56] hence decreasing the release of acetylcholine in the synapse, therefore, a decrease in acetylcholine, which might be attributed to impaired memory function observed in our study.

Another explication of $\mathrm{Cd}$ action on affective and cognitive disorders was found in the results of examination of same parameters in hippocampus reported in this study. We demonstrate that Cd exposure increased LPO levels, accompanied by a significant increase in NO levels in the hippocampus in male and female rats. This results are in agreement with several recent studies showing an increase in LPO and NO levels in the hippocampus which suggest an elevation of oxidative stress, following Cd administration in rat [19] [33] [57] [58] [59] [60]. Also, a high NO levels in many tissues including hippocampus in rats exposed to Cd has been observed in the studies of Karaca [61] and Abdel Moneim [59]. Oxidative stress represented an imbalance between the production of Reactive Oxygen Species (ROS) including peroxides and free radicals, and the ability of antioxidant enzymes such as superoxide dismutase (SOD), catalase (CAT) and glutathione peroxidase (GPx) to readily detoxify the reactive intermediates [62]. This imbalance results in various alterations such as DNA [63], proteins [64] [65] [66] and lipid peroxidation [63] [67]. It is reported that, the oxidative damage mechanism caused by $\mathrm{Cd}$ intoxication might be related to its interaction with mitochondrial sites, leading to the breakdown of the mitochondrial potentials, a consequent reduction of intracellular thiols and antioxidants [68], causing thereafter free radical generation like hydroxyl radicals, superoxide anions, $\mathrm{H}_{2} \mathrm{O}_{2}$ and $\mathrm{NO}$ [55] [69] [70]. Generally, $\mathrm{NO}$ is produced at the cellular level from arginine and oxygen. This reaction is catalyzed by an enzyme: NO synthase (NOS). An increase in the expression of the NO synthase gene (iNOS) stimulated by $\mathrm{Cd}$ has been demonstrated in vivo and in vitro [71] [72]. In addi- 
tion, $\mathrm{NO}$ reacts with the superoxide ion $\left(\mathrm{O}_{2}^{-}\right)$to form the ion peroxynitrite $\left(\mathrm{ONOO}^{-}\right)$, a very reactive toxic molecule involved in neurodegenerative pathologies, it acts as a powerful oxidant capable of modifying the functioning of proteins, nucleic acids (DNA oxidation) and lipids (LPO) [73] [74], which might explain the increase in LPO observed in our study. Once the LPO is provoked, it is followed by a structural change in biological membranes [75] [76] [77] or other lipid-containing elements [78] [79] causing impaired membrane fluidity and inactivation of several membrane-bound enzymes [80], which provoke a cell death [81], leading to many degenerative illnesses in the central nervous system, as well as psychiatric disturbances [82]. Also, numerous recent studies have shown an association between the disruption of behavioral functioning and high levels in LPO in the hippocampus [19] [33] [41].

Our hypothesis is that behavioral dysfunction observed in the present study (depression-like, anxiety-like and memory deficit) after chronic administration of Cd, might be linked to an increase in LPO and NO levels in the hippocampus and/or other brain areas. With regard to affective disorder, this could cause death of $5 \mathrm{HT}$ or other neurotransmitter neurons and consequently a decrease in $5 \mathrm{HT}$ brain levels. In this sense, a decrease in levels of 5-HT, dopamine in all regions of the brain including the anterior brain (hippocampus and striatum) has been shown $24 \mathrm{~h}$ after exposure to Cd [41] [42]. Concerning the memory process, the same mechanism of cellular death would be at the origin of neuronal degeneration, especially those releasing the $\mathrm{ACh}$, causing a decrease in the release of the neurotransmitter. An association between impairment of learning and decreased brain cholinergic activity has well established [51].

In addition, in our study, dose and sex dependent effect was well established; the effects of $\mathrm{Cd}$ on depression-like and anxiety-like being more pronounced in males than in females. This sexual dimorphism suggests the involvement of sexual hormones in the modulation of affective disorders by regulating neurotransmitter synthesis release or actions. In this sense, gonadal hormones contribute to the anatomical or functional characteristics of several neurotransmitter systems such as serotoninergic (5-HT) and gabaergic (GABA) systems that regulate anxiety and depression [83] [84] [85]. Edinger and Frye confirmed that sexual experience is associated with lower levels of anxiety-like behaviour and higher levels of androgen secretion [86]. It is known that testosterone elevations were associated with reduced male anxiety [83] [84] [85] [87]. Gonadectomy (GDX) in male rats would increase anxiety-like behaviour, an effect which would be reversed by systemic administration of dihydrotestosterone (DHT). Testosterone reduced anxiety-like behaviour through actions of its $5 \alpha$-reduced metabolite, DHT [88]. A high level of anxiety-like behaviour associated with lower levels of testosterone has observed in rat following cd exposure [88]; in male rats, injection of Cd at $2.5 \mathrm{mg} / \mathrm{kg}$ subcutaneously for four weeks significantly decreasing testosterone levels [89]. Cd administration significantly increased NO production [70], causing a decrease in testosterone synthesis in the Leydig cells through 
acting centrally on the pituitary gland and inhibiting LH secretion [90].

On the other hand, numerous studies showed that uptake and accumulation of Cd were more in the males when compared to female rats [91] [92]. This might be related to higher levels of metallothionein in female rats, which plays roles in Cd toxicity, transportation and detoxification, and which is increased by b-estradiol and progesterone administration [93]. Following subcutaneous $\mathrm{Cd}$ administration to male and female rats, liver metallothionein levels in female rats were reported to be higher than those in male ones [94]. Considering the basal metabolism of female rats, estrogen and progesterone levels are very high compared to those in male rats [95]. Therefore, metallothionein levels would be expected to be higher in females than in males, which might be explain the sex-dependent effect of this metal. In addition, Cd exerts estrogen-like activity and can elicit some typical estrogenic responses in rodents upon intraperitoneal (i.p.) injection. This route of administration was used in several rodent studies with Cd [96] [97] [98]. In ovariectomized female Wistar rats, the estrogenic activity of $\mathrm{CdCl}_{2}$ was observed after i.p. injection at doses between 0.00005 and 2 $\mathrm{mg} / \mathrm{kg}$ b.w [99]. It can activate the estrogen-receptor $\alpha$ (ER $\alpha$ ) via high-affinity interaction with the hormone-binding domain [100], contributing consequently to the high incidence of hormone-related.

\section{Conclusion}

This study suggests that people living in heavy metal pollution environments and continuous exposure to Cd may eventually lead to behavioral pathologies such as affective and cognitive disorders.

\section{Acknowledgements}

This work was supported by CNRST and faculty of Sciences University Ibn Tofaïl, kenitra. Thanks to Mr, A. REZQUAOUI, O. ZGHARI from Unit of Nervous and Endocrine Physiology, Laboratory of Genetics, Neuroendocrinology and Biotechnology, University Ibn Tofail, Kenitra, Morocco, for their help and assistance.

\section{References}

[1] Goyer, R.A. and Clarkson, T.W. (1996) Toxic Effects of Metals. In Amdur, M.O., Doull, J.D. and Klaassen, C.D., Eds., Casarett and Doulf s Toxicology, 4th Edition, Pergamon Press, New York, 623-680.

[2] Mortada, W.I., Sobh, M.A., El-Defrawy, M.M. and Farahat, S.E. (2002) Reference Intervals of Cadmium, Lead, and Mercury in Blood, Urine, Hair, and Nails among Residents in Mansoura City, Nile Delta, Egypt. Environmental Research, 90, 104-110. https://doi.org/10.1006/enrs.2002.4396

[3] Jones, M.M. and Cherian, M.G. (1990) The Search for Chelate Antagonists for Chronic Cadmium Intoxication. Toxicology, 62, 1-25. https://doi.org/10.1016/0300-483X(90)90027-E

[4] Zadorozhnaja, T.D., Little, R.E., Miller, R.K., Mendel, N.A., Taylor, R.J., Presley, B.J. 
and Gladen, B.C. (2013) Concentrations of Arsenic, Cadmium, Copper, Lead, Mercury, and Zinc in Human Placentas from Two Cities in Ukraine. Journal of Toxicology and Environmental Health, 61, 255-263.

[5] Shukla, A., Shukla, G.S. and Srimal, R. (1996) Cadmium-Induced Alterations in Blood-Brain Barrier Permeability and Its Possible Correlation with Decreased Microvessel Antioxidant Potential in Rat. Human \& Experimental Toxicology, 15, 400-405.

[6] Pihl, R.O. and Parkes, M. (1977) Hair Element Content in Learning Disabled Children. Science, 198, 204-206. https://doi.org/10.1126/science.905825

[7] Cao, Y., Chen, A., Radcliffe, J., Dietrich, K.N., Jones, R.L., Caldwell, K. and Rogan, W.J. (2009) Postnatal Cadmium Exposure, Neurodevelopment, and Blood Pressure in Children at 2, 5, and 7 Years of Age. Environmental Health Perspectives, 117, 1580-1586. https://doi.org/10.1289/ehp.0900765

[8] Okuda, B., Iwamoto, Y., Tachibana, H. and Sugita, M. (1997) Parkinsonism after Acute Cadmium Poisoning. Clinical Neurology and Neurosurgery, 99, 263-265. https://doi.org/10.1016/S0303-8467(97)00090-5

[9] Dési, I., Nagymajtényi, L. and Schulz, H. (1998) Behavioural and Neurotoxicological Changes Caused by Cadmium Treatment of Rats during Development. Journal of Applied Toxicology, 18, 63-70. https://doi.org/10.1002/(SICI)1099-1263(199801/02)18:1<63::AID-JAT475>3.0.CO; $\underline{2-Z}$

[10] Stoltenburg-Didinger, G. (1994) Neuropathology of the Hippocampus and Its Susceptibility to Neurotoxic Insult. Neurotoxicology, 15, 445-450.

[11] Altmann, L., Sveinsson, K. and Wiegand, H. (1991) Long-Term Potentiation in Rat Hippocampal Slices Is Impaired Following Acute Lead Perfusion. Neuroscience Letters, 128, 109-112. https://doi.org/10.1016/0304-3940(91)90771-K

[12] Brenneman, K., Wong, B., Buccellato, M., Costa, E.R., Gross, E. and Dorman, D.C. (2000) Direct Olfactory Transport of Inhaled Manganese ((54) $\mathrm{MnCl}(2))$ to the Rat Brain: Toxicokinetic Investigations in a Unilateral Nasal Occlusion Model. Toxicology and Applied Pharmacology, 169, 238-248.

[13] De Souza Predes, F., Diamante, M.A.S. and Dolder, H. (2010) Testis Response to Low Doses of Cadmium in Wistar Rats. International Journal of Experimental Pathology, 91, 125-131. https://doi.org/10.1111/j.1365-2613.2009.00692.x

[14] Lafuente, A., Marquez, N., Pazo, D. and Esquifino, A.I. (2001) Cadmium Effects on Dopamine Turnover and Plasma Levels of Prolactin, GH and ACTH. Journal of Physiology and Biochemistry, 57, 231-236.

[15] Wu, X., Guo, X., Wang, H., Zhou, S., Li, L., Chen, X., Wang, G., Liu, J., Ge, H.-S. and Ge, R.-S. (2017) A Brief Exposure to Cadmium Impairs Leydig Cell Regeneration in the Adult Rat Testis. Scientific Reports, 7, Article No. 6337. https://doi.org/10.1038/s41598-017-06870-0

[16] Wang, L.-S., Wang, L., Wang, L., Wang, G., Li, Z.-H. and Wang, J.-J. (2009) Effect of 1-Butyl-3-methylimidazolium Tetrafluoroborate on the Wheat (Triticum aestivum L.) Seedlings. Environmental Toxicology, 24, 296-303. https://doi.org/10.1002/tox.20435

[17] Jyostna, V. and Sudhakar, P. (2016) Neurobehavioral Alterations in Cadmium Exposed Rats. International Journal of Recent Scientific Research, 7, 9418-9424.

[18] Kaoud, H., Kamel, M.M., Abdel-Razek, H., Kamel, G.M. and Ahmed, K. (2010) Neurobehavioural, Neurochemical and Neuromorphological Effects of Cadmium in 
Male Rats. Journal of American Science, 6, 189-202.

[19] Haider, S., Anis, L., Batool, Z., Sajid, I., Naqvi, F., Khaliq, S. and Ahmed, S. (2014) Short Term Cadmium Administration Dose Dependently Elicits Immediate Biochemical, Neurochemical and Neurobehavioral Dysfunction in Male Rats. Metabolic Brain Disease, 30, 83-92. https://doi.org/10.1007/s11011-014-9578-4

[20] Carola, V., D’Olimpio, F., Brunamonti, E., Mangia, F. and Renzi, P. (2002) Evaluation of the Elevated Plus-Maze and Open-Field Tests for the Assessment of Anxiety-Related Behaviour in Inbred Mice. Behavioural Brain Research, 134, 49-57. https://doi.org/10.1016/S0166-4328(01)00452-1

[21] Gentsch, C., Lichtsteiner, M. and Feer, H. (1987) Open Field and Elevated Plus-Maze: A Behavioural Comparison between Spontaneously Hypertensive (SHR) and Wistar-Kyoto (WKY) Rats and the Effects of Chlordiazepoxide. Behavioural Brain Research, 25, 101-107. https://doi.org/10.1016/0166-4328(87)90003-9

[22] Alicia, A. and Cheryl, A. (2007) The Use of the Elevated Plus Maze as an Assay of Anxiety-Related Behavior in Rodents. NIH Public Access, 2, 322-328.

[23] Naranjo-Rodriguez, E.B., Osornio, A.O., Hernandez-Avitia, E., Mendoza-Fernandez, V. and Escobar, A. (2000) Anxiolytic-Like Actions of Melatonin, 5-Metoxytryptophol, 5-Hydroxytryptophol and Benzodiazepines on a Conflict Procedure. Progress in Neuro-Psychopharmacology \& Biological Psychiatry, 24, 117-129. https://doi.org/10.1016/S0278-5846(99)00075-5

[24] Porsolt, R.D., Anton, G., Blavet, N. and Jalfre, M. (1978) Behavioural Despair in Rats: A New Model Sensitive to Antidepressant Treatments. European Journal of Pharmacology, 47, 379-391. https://doi.org/10.1016/0014-2999(78)90118-8

[25] Benabid, N., Mesfioui, A. and Ouichou, A. (2008) Effects of Photoperiod Regimen on Emotional Behaviour in Two Tests for Anxiolytic Activity in Wistar Rat. Brain Research Bulletin, 75, 53-59. https://doi.org/10.1016/j.brainresbull.2007.07.016

[26] Sierksma, A.S.R., Van Den Hove, D.L.A., Pfau, F., Philippens, M., Bruno, O., Fedele, E., Ricciarelli, R., Steinbusch, H.W.M., Vanmierlo, T. and Prickaerts, J. (2014) Improvement of Spatial Memory Function in APPswe/PS1dE9 Mice after Chronic Inhibition of Phosphodiesterase Type 4D. Neuropharmacology, 77, 120-130.

[27] Morris, R. (1984) Developments of a Water-Maze Procedure for Studying Spatial Learning in the Rat. Journal of Neuroscience Methods, 11, 47-60. https://doi.org/10.1016/0165-0270(84)90007-4

[28] Wong, A. and Brown, R.E. (1984) Age-Related Changes in Visual Acuity, Learning and Memory in C57BL/6J and DBA/2J Mice. Neurobiology of Aging, 11, 47-60.

[29] Chao, C.C., Hu, S., Molitor, T.W., Shaskan, E.G., Peterson, P.K., Cha, C.C., Hu, S., Molitor, T.W., Shaskan, E. and Peterson, P.K. (1992) injury via a Nitric Oxide Mechanism. Activated Microglia Mediate Oxide Neuronal Cell Injury via a Nitric Mechanism. The Journal of Immunology, 149, 2736-2741.

[30] Draper, H.H. and Hadley, M. (1990) Malondialdehyde Determination as Index of Lipid Peroxidation. Methods in Enzymology, 186, 421-431. https://doi.org/10.1016/0076-6879(90)86135-I

[31] Freitas, R.M., Sousa, F.C.F., Vasconcelos, S.M.M., Viana, G.S.B. and Fonteles, M.M.F. (2004) Pilocarpine-Induced Status Epilepticus in Rats: Lipid Peroxidation Level, Nitrite Formation, GABAergic and Glutamatergic Receptor Alterations in the Hippocampus, Striatum and Frontal Cortex. Pharmacology Biochemistry and Behavior, 78, 327-332. https://doi.org/10.1016/j.pbb.2004.04.004

[32] Lister, R.G. (1987) The Use of a Plus-Maze to Measure Anxiety in the Mouse. Psy- 
chopharmacology (BerI), 92, 180-185. https://doi.org/10.1007/BF00177912

[33] Abdalla, F.H., Schmatz, R., Cardoso, A.M., Carvalho, F.B., Baldissarelli, J., de Oliveira, J.S., Rosa, M.M., Gonalves Nunes, M., Rubin, M.A., da Cruz, I.B.M., Barbisan, F., Dressler, V.L., Pereira, L.B., Schetinger, M.R.C., Morsch, V.M., Gonalves, J.F. and Mazzanti, C.M. (2014) Quercetin Protects the Impairment of Memory and Anxiogenic-Like Behavior in Rats Exposed to Cadmium: Possible Involvement of the Acetylcholinesterase and $\mathrm{Na}+, \mathrm{K}+-\mathrm{ATPase}$ Activities. Physiology \& Behavior, 135, 152-167.

[34] Minetti, A. and Reale, C.A. (2006) Sensorimotor Developmental Delays and Lower Anxiety in Rats Prenatally Exposed to Cadmium. Journal of Applied Toxicology, 26, 35-41. https://doi.org/10.1002/jat.1102.

[35] Méndez-Armenta, M. and Ríos, C. (2007) Cadmium Neurotoxicity. Environmental Toxicology and Pharmacology, 23, 350-358. https://doi.org/10.1016/j.etap.2006.11.009

[36] Gonçalves, J.F., Fiorenza, A.M., Spanevello, R.M., Mazzanti, C.M., Bochi, G.V., Antes, F.G., Stefanello, N., Rubin, M.A., Dressler, V.L., Morsch, V.M. and Schetinger, M.R.C. (2010) N-Acetylcysteine Prevents Memory Deficits, the Decrease in Acetylcholinesterase Activity and Oxidative Stress in Rats Exposed to Cadmium. Chemico-Biological Interactions, 186, 53-60. https://doi.org/10.1016/j.cbi.2010.04.011

[37] De Castro, E., Silva, E., Ferreira, H., Cunha, M., Bulcão, C., Sarmento, C., De Oliveira, J. and Fregoneze, J.B. (1996) Effect of Central Acute Administration of Cadmium on Drinking Behavior. Pharmacology Biochemistry and Behavior, 53, 687-693. https://doi.org/10.1016/0091-3057(95)02070-5

[38] Webster, W.S. and Valois, A. (1981) The Toxic Effects of Cadmium on the Neonatal Mouse CNS. Journal of Neuropathology \& Experimental Neurology, 40, 247-257.

[39] File, S.E., Kenny, P.J. and Cheeta, S. (2000) The Role of the Dorsal Hippocampal Serotonergic and Cholinergic Systems in the Modulation of Anxiety. Pharmacology Biochemistry and Behavior, 66, 65-72. https://doi.org/10.1016/S0091-3057(00)00198-2

[40] Kamel, M.M., El Razek, A.H.A., Ahmed, K.A. and Kamel, G.M. (2011) Exposure of Adult Male Rats to Cadmium: Assessment of Sexual Behaviour, Fertility, Aggression as Well as Anxiety Like Behaviour with Special Reference to Biochemical and Pathological Alterations. Life Science Journal, 8, 106-119.

[41] Abu-Taweel, G.M., Ajarem, J.S. and Ahmad, M. (2013) Protective Effect of Curcumin on Anxiety, Learning Behavior, Neuromuscular Activities, Brain Neurotransmitters and Oxidative Stress Enzymes in Cadmium Intoxicated Mice. Journal of Behavioral and Brain Science, 3, 74-84. https://doi.org/10.4236/jbbs.2013.31008

[42] Lafuente, A., Fenández-Rey, E., Seara, R., Pérez-Lorenzo, M. and Esquifino, A.I. (2001) Alternate Cadmium Exposure Differentially Affects Amino Acid Metabolism within the Hypothalamus, Median Eminence, Striatum and Prefrontal Cortex of Male Rats. Neurochemistry International, 39, 187-192. https://doi.org/10.1016/S0197-0186(01)00029-8

[43] Andersson, H., Petersson-Grawé, K., Lindqvist, E., Luthman, J., Oskarsson, A. and Olson, L. (1997) Low-Level Cadmium Exposure of Lactating Rats Causes Alterations in Brain Serotonin Levels in the Offspring. Neurotoxicology and Teratology, 19, 105-115. https://doi.org/10.1016/S0892-0362(96)00218-8

[44] Lalonde, R. (2002) The Neurobiological Basis of Spontaneous Alternation. Neuros- 
cience \& Biobehavioral Reviews, 26, 91-104.

https://doi.org/10.1016/S0149-7634(01)00041-0

[45] Kiraly, E. and Jones, D.G. (1982) Dendritic Spine Changes in Rat Hippocampal Pyramidal Cells after Postnatal Lead Treatment: A Golgi Study. Experimental Neurology, 77, 236-239. https://doi.org/10.1016/0014-4886(82)90158-3

[46] Alfano, D.P. and Petit, T.L. (1982) Neonatal Lead Exposure Alters the Dendritic Development of Hippocampal Dentate Granule Cells. Experimental Neurology, 75, 275-288. https://doi.org/10.1016/0014-4886(82)90160-1

[47] Łukawski, K., Nieradko, B. and Sieklucka-Dziuba, M. (2005) Effects of Cadmium on Memory Processes in Mice Exposed to Transient Cerebral Oligemia. Neurotoxicology and Teratology, 27, 575-584. https://doi.org/10.1016/j.ntt.2005.05.009

[48] Méndez-Armenta, M., Barroso-Moguel, R., Villeda-Hernández, J., Nava-Ruíz, C. and Ríos, C. (2001) Histopathological Alterations in the Brain Regions of Rats after Perinatal Combined Treatment with Cadmium and Dexamethasone. Toxicology, 161, 189-199. https://doi.org/10.1016/S0300-483X(01)00349-3

[49] Skutella, T. and Nitsch, R. (2001) New Molecules for Hippocampal Development. Trends in Neurosciences, 24, 107-113. https://doi.org/10.1016/S0166-2236(00)01717-3

[50] Decker, M.W. and McGaugh, J.L. (1991) The Role of Interactions between the Cholinergic System and Other Neuromodulatory Systems in Learing and Memory, Synapse, 7, 151-168. https://doi.org/10.1002/syn.890070209

[51] Flicker, C., Dean, R.L., Watkins, D.L., Fisher, S.K. and Bartus, R.T. (1983) Behavioral and Neurochemical Effects Following Neurotoxic Lesions of a Major Cholinergic Input to the Cerebral Cortex in the Rat. Pharmacology Biochemistry and Behavior, 18, 973-981. https://doi.org/10.1016/S0091-3057(83)80023-9

[52] Cory-Slechta, D.A. and Pokora, M.J. (1995) Lead-Induced Changes in Muscarinic Cholinergic Sensitivity. Neurotoxicology, 16, 337-347.

[53] Forget, J., Pavillon, J., Beliaeff, B. and Bocquené, G. (1999) Joint Action of Pollutant Combinations (Pesticides and Metals) on Survival (LC50 Values) and Acetylcholinesterase Activity of Tigriopus brevicornis Copepoda, Harpacticoida. Environmental Toxicology and Chemistry, 18, 912-918. https://doi.org/10.1002/etc.5620180514

[54] Tomlinson, G., Mutus, B. and McLennan, I. (1981) Activation and Inactivation of Acetylcholinesterase by Metal Ions. Canadian Journal of Biochemistry, 59, 728-735. https://doi.org/10.1139/o81-101

[55] Casalino, E., Sblano, C. and Landriscina, C. (1997) Enzyme Activity Alteration by Cadmium Administration to Rats: The Possibility of Iron Involvement in Lipid Peroxidation. Archives of Biochemistry and Biophysics, 346, 171-179. https://doi.org/10.1006/abbi.1997.0197

[56] Carageorgiou, H., Tzotzes, V., Sideris, A., Zarros, A. and Tsakiris, S. (2005) Cadmium Effects on Brain Acetylcholinesterase Activity and Antioxidant Status of Adult Rats: Modulation by Zinc, Calcium and L-Cysteine Co-Administration. Basic \& Clinical Pharmacology \& Toxicology, 97, 320-324. https://doi.org/10.1111/j.1742-7843.2005.pto_174.x

[57] Kanter, M., Unsal, C., Aktas, C. and Erboga, M. (2013) Neuroprotective Effect of Quercetin against Oxidative Damage and Neuronal Apoptosis Caused by Cadmium in Hippocampus. Toxicology and Industrial Health, 32, 541-550. https://doi.org/10.1177/0748233713504810 
[58] Kim, W., Kim, D.W., Yoo, D.Y., Jung, H.Y., Nam, S.M., Kim, J.W., Hong, S.-M., Kim, D.-W., Choi, J.H., Moon, S.M., Yoon, Y.S. and Hwang, I.K. (2014) Dendropanax Morbifera Léveille Extract Facilitates Cadmium Excretion and Prevents Oxidative Damage in the Hippocampus by Increasing Antioxidant Levels in Cadmium-Exposed Rats. BMC Complementary and Alternative Medicine, 14, 428. https://doi.org/10.1186/1472-6882-14-428

[59] Abdel Moneim, A.E., Bauomy, A.A., Diab, M.M.S., Shata, M.T.M., Al-Olayan, E.M. and El-Khadragy, M.F. (2014) The Protective Effect of Physalis peruviana L. against Cadmium-Induced Neurotoxicity in Rats. Biological Trace Element Research, 160, 392-399. https://doi.org/10.1007/s12011-014-0066-9

[60] Mukherjee, R., Desai, F., Singh, S., Gajaria, T., Singh, P.K., Baxi, D.B., Sharma, D., Bhatnagar, M. and Ramachandran, A.V. (2010) Melatonin Protects against Alterations in Hippocampal Cholinergic System, Trace Metals and Oxidative Stress Induced by Gestational and Lactational Exposure to Cadmium. EXCLI Journal, 9, 119-132.

[61] Karaca, S. and Eraslan, G. (2013) The Effects of Flaxseed Oil on Cadmium-Induced Oxidative Stress in Rats. Biological Trace Element Research, 155, 423-430. https://doi.org/10.1007/s12011-013-9804-7

[62] Sies, H. (1997) Oxidative Stress: Oxidants and Antioxidants. Experimental Physiology, 82, 291-295. https://doi.org/10.1113/expphysiol.1997.sp004024

[63] Gaté, L., Paul, J., Ba, G.N., Tew, K.D. and Tapiero, H. (1999) Oxidative Stress Induced in Pathologies: The Role of Antioxidants. Biomedicine \& Pharmacotherapy, 53, 169-180. https://doi.org/10.1016/S0753-3322(99)80086-9

[64] Thannickal, V.J. and Fanburg, B.L. (2000) Reactive Oxygen Species in Cell Signaling. American Journal of Physiology-Lung Cellular and Molecular Physiology, 279, L1005. https://doi.org/10.1152/ajplung.2000.279.6.L1005

[65] Hawkins, C.L. and Davies, M.J. (2001) Generation and Propagation of Radical Reactions on Proteins. Biochimica et Biophysica Acta (BBA)-Bioenergetics, 1504, 196-219. https://doi.org/10.1016/S0005-2728(00)00252-8

[66] Requena, J.R., Levine, R.L., Chao, C.-C. and Stadtman, E.R. (2001) Glutamic and Aminoadipic Semialdehydes Are the Main Carbonyl Products of Metal-Catalyzed Oxidation of Proteins. Proceedings of the National Academy of Sciences, 98, 69-74. https://doi.org/10.1073/pnas.98.1.69

[67] Yuan, X.M. and Brunk, U.T. (1998) Iron and LDL-Oxidation in Atherogenesis. APMIS, 106, 825-842. https://doi.org/10.1111/j.1699-0463.1998.tb00229.x

[68] López, E., Arce, C., Oset-Gasque, M.J., Cañadas, S. and González, M.P. (2006) Cadmium Induces Reactive Oxygen Species Generation and Lipid Peroxidation in Cortical Neurons in Culture. Free Radical Biology \& Medicine, 40, 940-951. https://doi.org/10.1016/j.freeradbiomed.2005.10.062

[69] Koizumi, T., Shirakura, H., Kumagai, H., Tatsumoto, H. and Suzuki, K.T. (1996) Mechanism of Cadmium-Induced Cytotoxicity in Rat Hepatocytes: Cadmium-Induced Active Oxygen-Related Permeability Changes of the Plasma Membrane. Toxicology, 114, 125-134. https://doi.org/10.1016/S0300-483X(96)03477-4

[70] Waisberg, M., Joseph, P., Hale, B. and Beyersmann, D. (2003) Molecular and Cellular Mechanisms of Cadmium Carcinogenesis. Toxicology, 192, 95-117. https://doi.org/10.1016/S0300-483X(03)00305-6

[71] Poliandri, A.H.B., Esquifino, A.I., Cano, P., Jiménez, V., Lafuente, A., Cardinali, D.P. and Duvilanski, B.H. (2006) In Vivo Protective Effect of Melatonin on Cad- 
mium-Induced Changes in Redox Balance and Gene Expression in Rat Hypothalamus and Anterior Pituitary. Journal of Pineal Research, 41, 238-246. https://doi.org/10.1111/j.1600-079X.2006.00360.x

[72] Poliandri, A.H.B., Velardez, M.O., Cabilla, J.P., Bodo, C.C.A., MacHiavelli, L.I., Quinteros, A.F. and Duvilanski, B.H. (2004) Nitric Oxide Protects Anterior Pituitary Cells from Cadmium-Induced Apoptosis. Free Radical Biology \& Medicine, 37, 1463-1471. https://doi.org/10.1016/j.freeradbiomed.2004.07.017

[73] Gisone, P., Boveris, A.D., Dubner, D., Perez, M.R., Robello, E. and Puntarulo, S. (2003) Early Neuroprotective Effect of Nitric Oxide in Developing Rat Brain. Irradiated in Utero, 24, 245-253.

[74] Hall, E.D., Detloff, M.R., Johnson, K., Kupina, N.C. and Al, H.E.T. (2004) Peroxynitrite-Mediated Protein Nitration and Lipid Peroxidation in a Mouse Model of Traumatic Brain Injury. Journal of Neurotrauma, 21, 9-20. https://doi.org/10.1089/089771504772695904

[75] Sevanian, A. and Hochstein, P. (1985) Mechanisms and Consequences of Lipid Peroxidation in Biological Systems. Annual Review of Nutrition, 5, 365-390. https://doi.org/10.1146/annurev.nu.05.070185.002053

[76] Pacifici, E.H.K., McLeod, L.L. and Sevanian, A. (1994) Lipid Hydroperoxide-Induced Peroxidation and Turnover of Endothelial Cell Phospholipids. Free Radical Biology \& Medicine, 17, 297-309. https://doi.org/10.1016/0891-5849(94)90016-7

[77] Comporti, M. (1985) Lipid Peroxidation and Cellular Damage in Toxic Liver Injury. Laboratory Investigation, 53, 599-623.

[78] Al-Mutairi, D.A., Craik, J.D., Batinic-Haberle, I. and Benov, L.T. (2007) Induction of Oxidative Cell Damage by Photo-Treatment with Zinc N-Methylpyridylporphyrin. Free Radical Research, 41, 89-96. https://doi.org/10.1080/10715760600952869

[79] Stark, G. (2005) Functional Consequences of Oxidative Membrane Damage. The Journal of Membrane Biology, 205, 1-16. https://doi.org/10.1007/s00232-005-0753-8

[80] Goel, A., Dani, V. and Dhawan, D.K. (2005) Protective Effects of Zinc on Lipid Peroxidation, Antioxidant Enzymes and Hepatic Histoarchitecture in Chlorpyrifos-Induced Toxicity. Chemico-Biological Interactions, 156, 131-140. https://doi.org/10.1016/j.cbi.2005.08.004

[81] Emerit, J., Klein, J.M., Coutellier, A. and Congy, F. (1991) Free Radicals and Lipid Peroxidation in Cell Biology: Physiopathologic Prospects. Pathologie Biologie, 39, 316-327.

[82] Khanna, R.S., Negi, R., Pande, D., Khanna, S. and Khanna, H.D. (2012) Markers of Oxidative Stress in Generalized Anxiety Psychiatric Disorder: Therapeutic Implications. Journal of Stress Physiology \& Biochemistry, 8, 32-38.

[83] Ouakki, S., El Mrabet, F.Z., Lagbouri, I., El Hessni, A., Mesfioui, A., Pévet, P., Challet, E. and Ouichou, A. (2013) Melatonin and Diazepam Affect Anxiety-Like and Depression-Like Behavior in Wistar Rats: Possible Interaction with Central GABA Neurotransmission. Journal of Behavioral and Brain Science, 3, 522-533. https://doi.org/10.4236/jbbs.2013.37055

[84] El Mrabet, F.Z., Ouakki, S., Mesfioui, A., El Hessni, A. and Ouichou, A. (2012) Pinealectomy and Exogenous Melatonin Regulate Anxiety-Like and Depressive-Like Behaviors in Male and Female Wistar Rats. Neuroscience and Medicine, 3, 394-403. https://doi.org/10.4236/nm.2012.34049 
[85] El Mrabet, F.Z., Lagbouri, I., Mesfioui, A., El Hessni, A. and Ouichou, A. (2012) The Influence of Gonadectomy on Anxiolytic and Antidepressant Effects of Melatonin in Male and Female Wistar Rats: A Possible Implication of Sex Hormones. Neuroscience and Medicine, 3, 162-173. https://doi.org/10.4236/nm.2012.32021

[86] Edinger, K.L. and Frye, C.A. (2007) Sexual Experience of Male Rats Influences Anxiety-Like Behavior and Androgen Levels. Physiology \& Behavior, 92, 443-453. https://doi.org/10.1016/j.physbeh.2007.04.018

[87] Aikey, J.L., Nyby, J.G., Anmuth, D.M. and James, P.J. (2002) Testosterone Rapidly Reduces Anxiety in Male House Mice (Mus Musculus). Hormones and Behavior, 42, 448-460. https://doi.org/10.1006/hbeh.2002.1838

[88] Edinger, K.L. and Frye, C.A. (2006) Intrahippocampal Administration of an Androgen Receptor Antagonist, Flutamide, can Increase Anxiety-Like Behavior in Intact and DHT-Replaced Male Rats. Hormones and Behavior, 50, 216-222. https://doi.org/10.1016/j.yhbeh.2006.03.003

[89] Elharabi, F.B. and Gatie, S.J. (2010) The Effects of Cadmium Chlorid (CdCl2) on the Functions of Reproductive System of the Male Mice. Journal of Applied Toxicology, 11, 229-235.

[90] Dobashi, M., Fujisawa, M., Yamazaki, T., Okuda, Y., Kanzaki, M., Tatsumi, N., Tsuji, T., Okada, H. and Kamidono, S. (2001) Inhibition of Steroidogenesis in Leydig Cells by Exogenous Nitric Oxide Occurs Independently of Steroidogenic Acute Regulatory Protein (Star) mRNA. Archives of Andrology, 47, 203-209. https://doi.org/10.1080/014850101753145915

[91] Nwokocha, C.R., Nwokocha, M.I., Owu, D., Edidjana, E., Nwogbo, N., Ekpo, U. and Ufearo, C.S. (2011) Estimation of Absorbed Cadmium in Tissues of Male and Female Albino Rats through Different Routes of Administration. Nigerian Journal of Physiological Sciences, 26, 97-101.

[92] Lanszki, J., Orosz, E. and Sugár, L. (2009) Metal Levels in Tissues of Eurasian Otters (Lutra lutra) from Hungary: Variation with Sex, Age, Condition and Location. Chemosphere, 74, 741-743. https://doi.org/10.1016/j.chemosphere.2008.10.022

[93] Bracken, W.M. and Klaassen, C.D. (1987) Induction of Metallothionein by Steroids in Rat Primary Hepatocyte Cultures. Toxicology and Applied Pharmacology, 87, 381-388. https://doi.org/10.1016/0041-008X(87)90242-0

[94] Shaikh, Z.A., Jordan, S.A. and Tewari, P. (1993) Cadmium Disposition and Metallothionein Induction in Mice: Strain-, Sex-, Age-, and Dose-Dependent Differences. Toxicology, 80, 51-70. https://doi.org/10.1016/0300-483X(93)90076-5

[95] Kara, H. (2005) Effect of Single Dose Cadmium Chloride Administration on Oxidative Stress in Male and Female Rats. Turkish Journal of Veterinary \& Animal Sciences, 29, 37-42.

[96] Zhang, W., Pang, F., Huang, Y., Yan, P. and Lin, W. (2008) Cadmium Exerts Toxic Effects on Ovarian Steroid Hormone Release in Rats. Toxicology Letters, 182, 18-23. https://doi.org/10.1016/j.toxlet.2008.07.016

[97] Johnson, M.D., Kenney, N., Stoica, A., Hilakivi-Clarke, L., Singh, B., Chepko, G., Clarke, R., Sholler, P.F., Lirio, A., Foss, C., Reiter, R., Trock, B., Paik, S. and Martin, M.B. (2003) Cadmium Mimics the In Vivo Effects of Estrogen in the Uterus and Mammary Gland. Nature Medicine, 9, 1081-1084. https://doi.org/10.1038/nm902

[98] Alonso-González, C., González, A., Mazarrasa, O., Güezmes, A., Sánchez-Mateos, S., Martínez-Campa, C., Cos, S., Sánchez-Barceló, E.J. and Mediavilla, M.D. (2007) Melatonin Prevents the Estrogenic Effects of Sub-Chronic Administration of Cadmium on Mice Mammary Glands and Uterus. Journal of Pineal Research, 42, 
403-410. https://doi.org/10.1111/j.1600-079X.2007.00434.x

[99] Höfer, N., Diel, P., Wittsiepe, J., Wilhelm, M. and Degen, G.H. (2009) Dose- and Route-Dependent Hormonal Activity of the Metalloestrogen Cadmium in the Rat Uterus. Toxicology Letters, 191, 123-131.

https://doi.org/10.1016/j.toxlet.2009.08.014

[100] Stoica, A., Katzenellenbogen, B.S. and Martin, M.B. (2000) Activation of Estrogen Receptor-Alpha by the Heavy Metal Cadmium. Molecular Endocrinology, 14, 545-553. 